\title{
فعالية المدرسة الثانوية العامة في تحقيق كفايات الاقتصاد المعرفي (دراسة مقارنة بين مصر والولايات المتحدة الأمريكية)
}

\author{
م / وفاء ابراهيم الصادو \\ مدرس بقسم التربية المقارنة والإدارة التزبوية \\ كلية التربية - جامعة السويس \\ ملخص البحث: \\ هدف البحث الحالي إلى التعرف على فعالية المدرسة الثانوية العامة في تحقيـق كفايـات

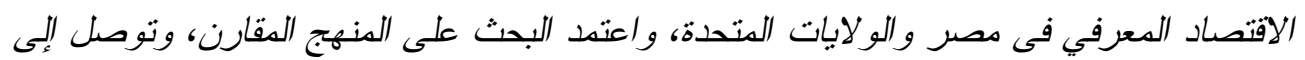

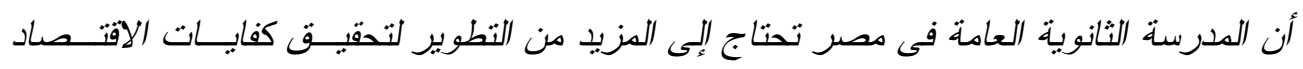

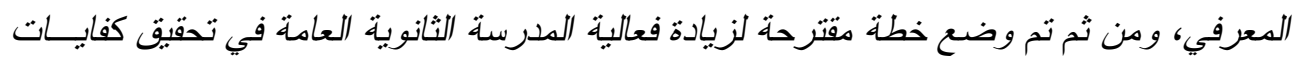

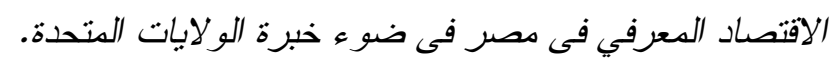

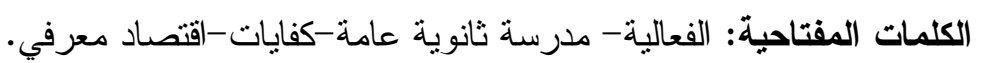

\section{Abstract:}

The current research aims to analyze the Effectiveness of general secondary school in achieving knowledge economy competencies in Egypt in the light of American experience. The research depended on the comparative method, It revealed many differences in the role of general secondary school in achieving knowledge economy competencies between Egypt and United States, so current research set a proposed conception to improve the Effectiveness of general secondary school in achieving knowledge economy competencies in Egypt in the light of American experience

Key words: Effectiveness- general secondary school- competenciesknowledge economy

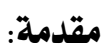

و أساليب منطورة مؤثرة في نمط التتمية وفي

أثنكال الأنظمة الاجتماعية و الاقتصادية (')

ويحتل التعــيم مكانسـة بــارزة فــي

اهتمامات جميع دول العالم لما يسهم به فــي

تكوين الفرد و إير از مو اهبه، وطاقاته المبدعة
لقد شهد العالم في السنوات الأخيــرة

تغير ات في معظم مجالات الحياة، حيث النمو

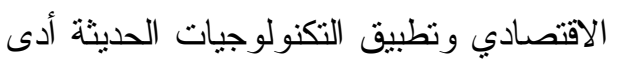

إلى تسارع نركيبه الاقتصاد، مع بروز أنماط

عمل و إنتاج جديدة خاصة في قطاع الخدمات 
الناضبة إلى الموارد المعرفية المتجــددة فـي

تحقيق التتمية المستدامة.

لذا فإنه لا يمكن لأي اقتصاد أن ينمو

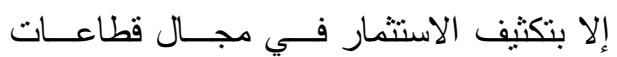

البشر،الذي أصبح أحد أهم عناصر العمليــة

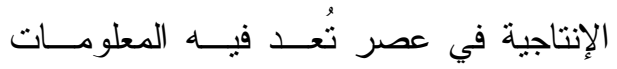

و التكنولوجيا هي المدخل لاقتصاد قوى، ولن

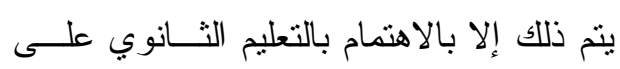

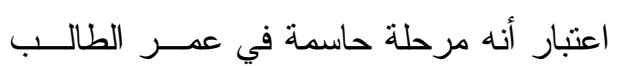

للالتحاق بسوق العمل أو التعليم الجامعي (r).

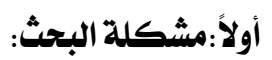

أن المعرفة كمورد متجــدد أصـــبــ

أهم محركات النـــو الاقتــصادي، و عائــــ الاستثمار في المعرفة يفوق عائد الاســثنمار في رأس المال المادي من حيث آثاره علـى الثى

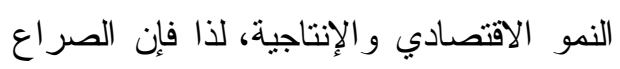

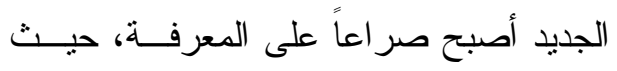
إنها تصنع القوة، وتوفر المال، وتوجد المواد

$$
\text { الخام وتفتح الأسواق. }
$$

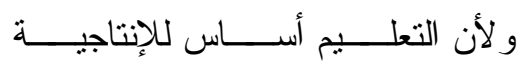

و التتافسية الاقتصادية، فيتعين على الحكومات أن توفر اليد العاملة الماهرة القــادرة علــى

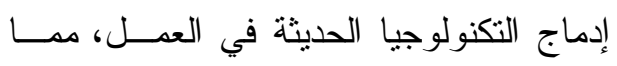
يدعو إلى تتامي الحاجة إلى دمج تكنولوجيــا المعلومات و الاتصالات فضلاً عن الاهتمــام

بالمهار ات الإبداعية في المنـــاهج التعليميــة

$$
\text { وبر امج التعلم مدى الحياة(؟). }
$$

وتحسين دوره في تتمية المجتمــع، وتعزيـز قدر اته علــى مو اجهـــة تحــديات الحاضـــر و المستقبل، فضلا عن دوره الفاعل فى نــشر هـر المعرفة وتتميتها بفروع العلم المختلفــة، لـــذا فإنه عملية حيوية تعود بثمرتها على المجتمع ذاته، ونظر اً لذلك فقد حظي باهتمام مخططي التتمية فى كثير من الدول كعامل رئيسي في منظومة التتمية المجتمعية، ومن ثم نز ايــدت

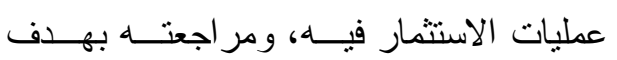
تطوير ه وتحديثه .

و إذا أريد للتعليم أن يكــون عمليــة تستمر طوال الحياة، فعلينا أن نعيد النظر فيه بشكل عام و التعليم الثانوي العام بشكل خاص من حيث المضمون و التتظيم، باعتباره حلقــة الوصل بين التعليم الأساسي والتعليم العــالي لي لـي و الجامعي، ونظر اً لدوره في إعداد الــشباب الـاب

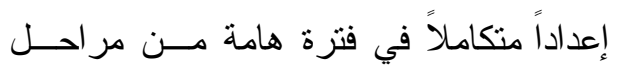
عمر هم (r)

و هناكَ حاجة ملحة إلى رفــع معـدل

النمو الاقتصادي، وقدر اته التتافسية، اعتمــادا

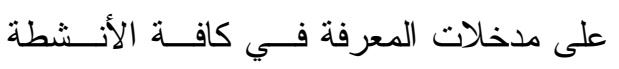
الإنتاجية، بغرض اكتساب ميــزات نتافـسية جديدة، وتتويع مصادر الدخل، و إعادة هيكلــة الاقتصاد الوطني، ومو اجهة التحديات العالمية

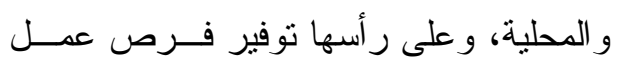
عالية الإنتاجية مرتفعة الأجر للأجيال القادمة، و التحول من الاعتماد على الموارد الطبيعيــة 
ه. زيادة البطالة بــين الــشباب و افتقـــار هم

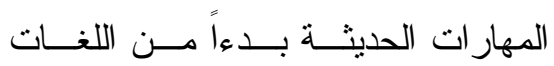

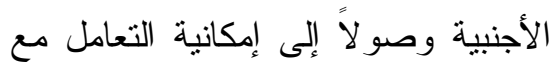

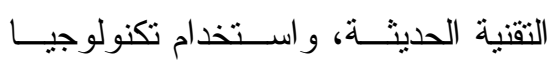
المعلومات. 7. ضعف المدرسة فــي إكــــاب الطالــبـ للمهار ات الابتكارية و إنتاج المعرفة.

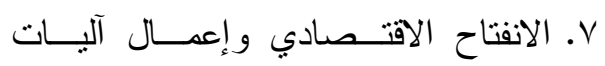

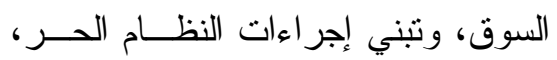

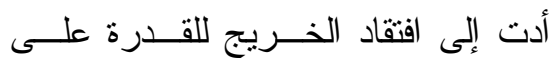

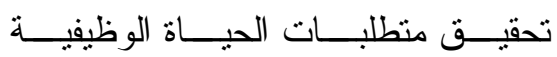

$$
\text { الحديثة) ("). }
$$

ثانياً: أسئلة البحث:

جاء البحث لمحاولة الإجابــة عـن

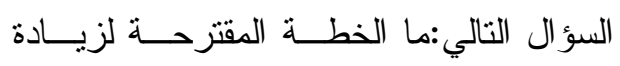

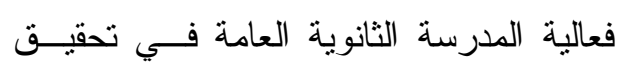
كفايات الاقتصاد المعرفي في مصر في ضوء خبرة الو لايات المتحدة؟ الافئ وللإجابة على هذا التساؤل الرئيس يتفــرع منه بعض الأسئلة الفرعية التالية:

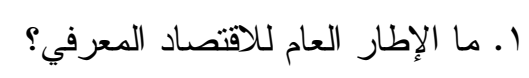

r. ما فعالية المدرسة الثانوية العامة بمصر

في تحقيق كفايات الاقتصاد المعرفي؟

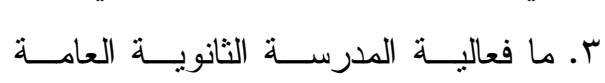

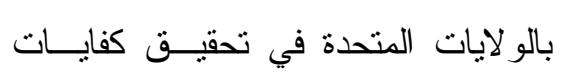

$$
\text { الاقتصاد المعرفي ؟ }
$$

ونظر اً لما يشهده المجتمع المـصري

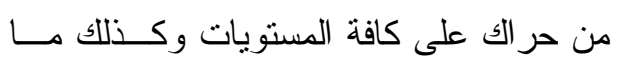

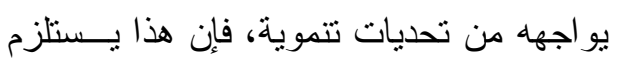

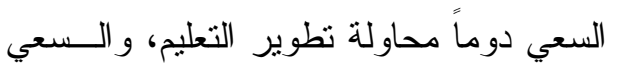
للتعرف على الخبرات التعليمية الناجحة و التي تساعد على تحقيق منطلبات مجتمع الاقتصاد

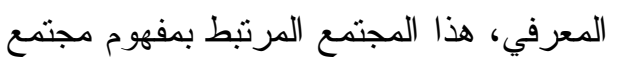

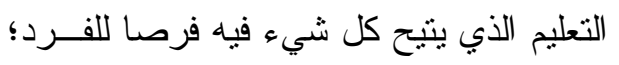

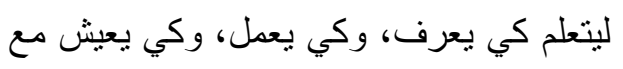
الآخرين، وكي يحقق ذاته.

وفى ظل نطور الاقتــصاد المعرفـي لعي على المستوى العالمي فإن التعلــيم الثــانوي

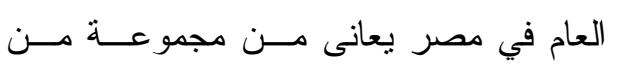

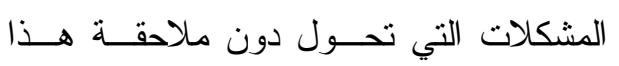
النطور منها: ا ـ سعى مصر للقضاء على الأمية، ومن ثم مناء

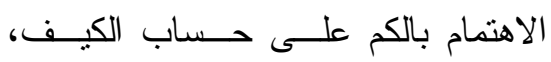

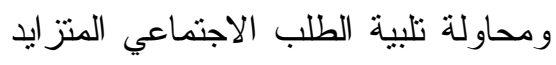
على التعليم.

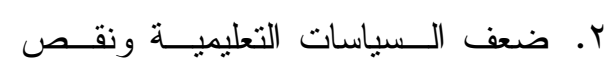

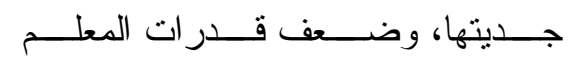

$$
\text { التدريسية. }
$$

r. غياب آليات منظمة للربط بين المدرسة

$$
\text { و المؤسسات البحثية و العلمية(ْ). }
$$

ع. شهذ التعليم المصري عدداً من محاولات

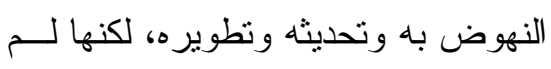

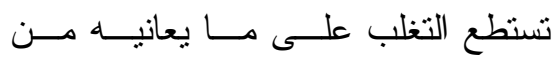
مشكلات و أزماته و إخفاقات. 


\begin{tabular}{|c|c|}
\hline رابعاً : أهمية البحث: & ـ ــــا التحليل المقــارن لفعاليـــة المدرســـة \\
\hline تبع أهمية البحث الحالي من النقاط التالية: & الثانوية العامــة فــي تحقيـق كفايــات \\
\hline ا ـ وضع بعض الخطوط العريــضة حــول & الاقتصاد المعرفي بين مصر و الولايــات \\
\hline الاقتصـاد المعرفي وعلاقتـــه بالمدرســة & 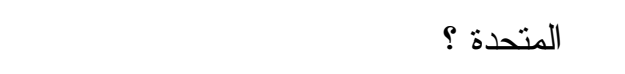 \\
\hline الثانوية العامة. & هـ ما الخطة المقترحة لزيادة فعالية المدرسة \\
\hline r. قد يفيد التحليل المقارن في الكثف عـن & الثانوية العامة بمصر في تحقيق كفايــات \\
\hline مشكلات المدرسة الثانوية العامة بمصر & الاقتصـاد المعرفي فـي ضــــــــــرة \\
\hline فيما يتعلق بالاقتصاد المعرفي. & الو لايات المتحدة؟ \\
\hline r. من الممكن أن يساعد التصور المقتــرح & 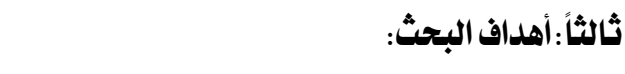 \\
\hline المسئولين عند تطوير المدرسة الثانويــة & يسعى البحث الحالي إلى تحقــق الأهــــــ \\
\hline العامة، ومن ثم التزكيز علــى تحقيـق & 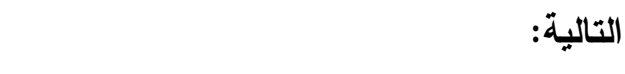 \\
\hline كفايات الاقتصاد المعرفي بها. & ا ـ التعرف على الإطـــار العــام للاقتــصـاد \\
\hline ساً حمبو الهحث & 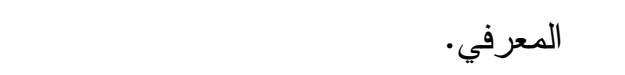 \\
\hline ركز البحث على الكثثف عن فعاليــة & r. الكثثف عن فعاليـــة المدرســـة الثانويــة \\
\hline المدرسة الثانوية العامة في تحقيــق كفايــات & العامة بمصر في تحقيق كفايات الاقتصاد \\
\hline الاقتصـاد المعرفي فــي مــصر و الولايـــات & المعرفي. \\
\hline المتحدة، وفى الحدود المكانيـــة ركــز علــى & ـــــديد فعالية المدرسة الثانويـــة العامــة \\
\hline مصر و الو لايات المتحدة، ومن الناحية الزمنية & بالو لايات المتحدة في تحقبـق كفايــات \\
\hline فقد أجرى البحث عام9 1 ـ. T. & الاقتصاد المعرفي. \\
\hline 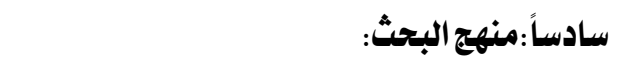 & عـ استعر اض التحليـلـل المقــارن لفعاليــة \\
\hline استخدمت الباحثة المــــهج المقــارن، & المدرسة الثنانوية العامة في تحقيق كفايات \\
\hline حيث يتم وصف إحدى الظو اهر أو القــضايا & الاقتصاد المعرفي بين مصر و الولايــات \\
\hline في دولتين أو أكثر ثم المقارنة بينهم ومحاولة & المتحدة. \\
\hline التوصل إلى الأسباب التي أدت إلــى وجـــود & هـ وضع خطـــة مقترحسـة لزيــادة فعاليــة \\
\hline اختلافات(V)، لذا فقد تتاول عن فعالية المدرسة & المدرسة الثانوية العامة بمصر في تحقيق \\
\hline الثانوية العامة في تحقيق كفايــات الاقتــــاد & كفايات الاقتصناد المعرفي فـي ضـــوء \\
\hline المعرفي فـي مــصر و الو لايـــات المتحـــدة & خبرة الو لايات المتحدة. \\
\hline
\end{tabular}




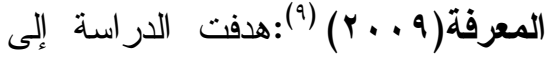

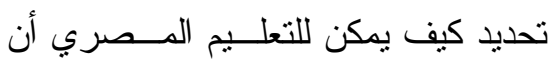

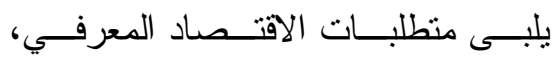

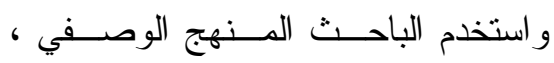

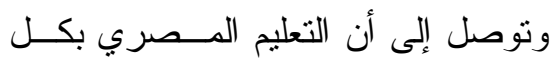
مستوياته يحتاج إلى نطوير شامل حتـى النعي

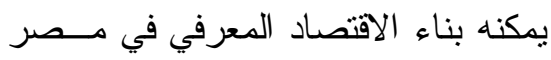
بالاعتماد على خريجيه.

r. دراسة سعد خضير :"الاقتصاد المعرفي أساس التنمية الاقتصادية والاجتماعيــة

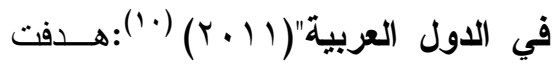
الدر اسة إلى التعــرف علــى العناصــر

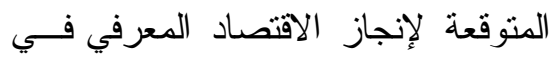

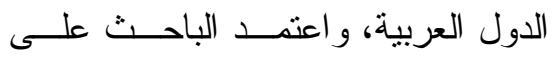
المنهج الوصفي، وتوصل إلى أن هنــاك لك الك

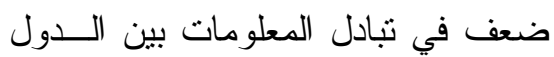
العربية، و إهمال الكفاءات العلمية التـي هي لب الاقتــصاد المعرفـي، وغيــاب إستر اتيجية صناعة وتـسـويق وتحويــلـل المعرفة لمنتجات، وسيادة البيروقر اطيــة في مختلف مناحي الحياة.

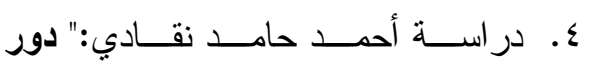
الاقتصاد المعرفي في التنمية الاقتصادية دراسة تحليلية بالتطبيق على الاقتــصاد

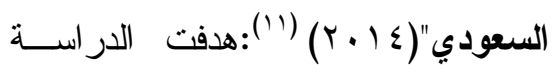
إلى التعرف على دور الاقتصاد المعرفي

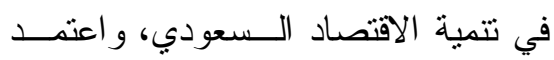

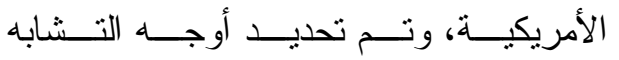
و الاختلاف بينهما، ومن ثم التوصل إلى نتائج تفيد البحث يمكن من خلالها زيــادة فعاليــة

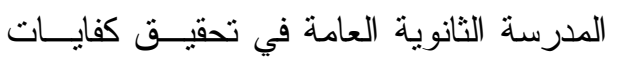

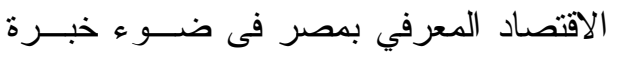
الو ل الايات المتحدة.

\section{سابعاً :الدراسات السابقة:}

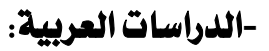

ا ـ. در اسة زكريا ســالم: " تطـــوير الأداء الإداري بالمدارس الثانوية العامة بمصر لمرئ في ضوء مدخل إدارة المعرفة

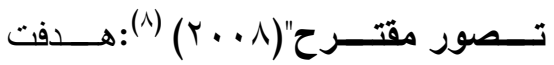
الدراسة إلى رصد الو اقع الحالي لــلأَداء

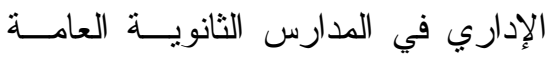
بمصر ، و اعتمدت الدراسة على المــنهج الوصفي، وتم تطبيق اســنبانه للوقــوف واعل

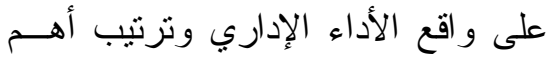
الصعوبات بالمدارس الثانويــة العامـــة وتوصلت إلى أنه يوجد فروق ذات دلالة إحصائية بين استجابات أفراد العينة فيما يتعلق بـسعي إدارة المدرســـة الثانويـــة العامة لاكتساب المعرفة ونقلها وتطبيقها،

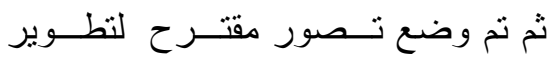
الأداء الإداري لهذه المدارس في ضـــو لهو لهو مدخل إدارة المعرفة. r. دراسة محمد سيد أبو السعود:"تطــوير

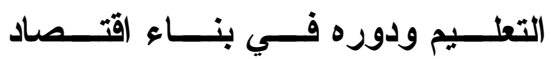


الاقتصاد المعرفي، بالإفادة من خبرتــي

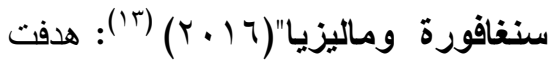
الدر اسة إلى بيان سياسات التعليم العـالي

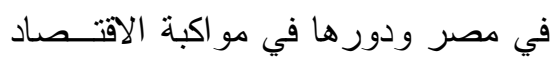

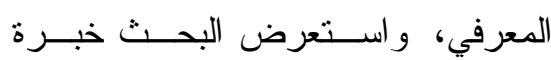

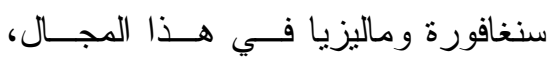
و اعتمد البحث على المــنهج المقــارن، وتوصل إلى أنه يجب نطوير سياســات

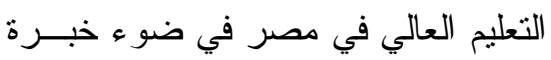

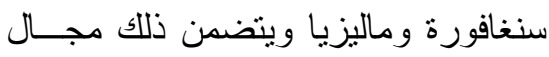

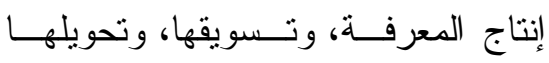
لمنتجات تسنطيع مو اجهة المنافسة علــى ولى ولى الصعيد الدولي.

V. . دراسة محمد أحمــد حسبين"دراســة مقارنة لدور الجامعة في التحول إلـى دلى

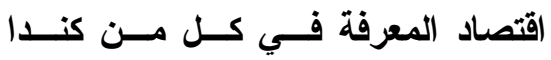
وسنغافورة و إمكانية الإفادة منهــــا فــي

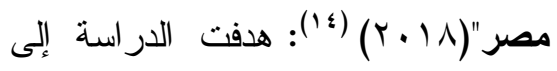

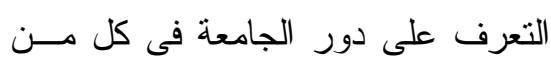

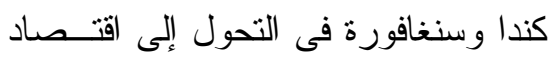

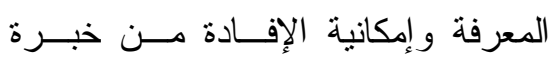

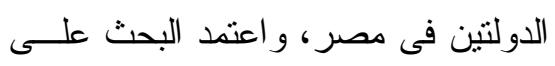

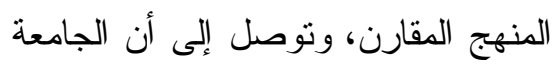

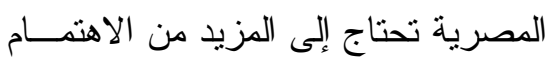
لكى يمكنها التحول إلى اقتصاد المعرفة، ونم تقديم رؤية مقترحة لـــــم الجهـــود
الباحث على المنهج الوصفي التحليلـي،

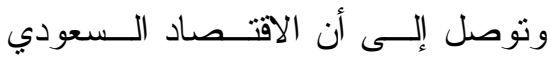

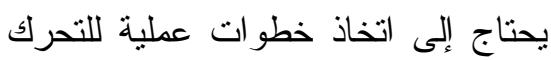

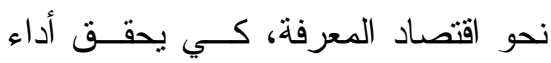
أفضل على المسنوى العالمي، وقطاعات الأعمال تحتاج إلى مزيد مــن الاهتمـــام و التحـــديث وبنـــاء القــدر ات لمــسايرة التحولات الاقتصادية الناجمة عن اقتصاد المعرفة. - الم

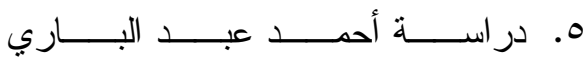
أحمد:"إستر اتيجية مقترحسة للإصــلاح

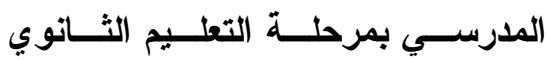

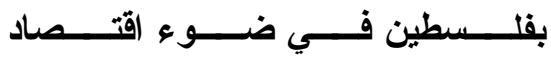

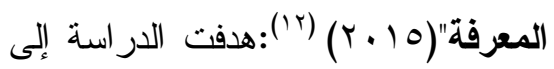
وضع إستر اتيجية لإصلاح التعليم الثانوي بفلسطين في ضوء اقتــصناد المعرفــة، واستعان الباحث بالمنهج الوصفي، مــع إعداد استبانه للتعرف على رأى بأى مــديري

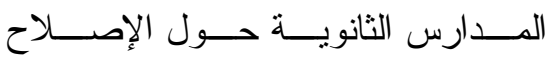

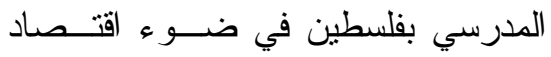
المعرفة، وتوصل إلى أن أهــم محسـاور

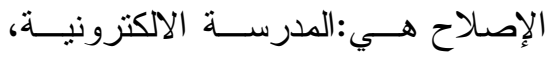

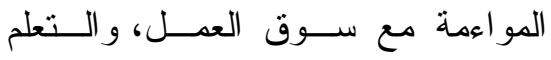
للتعــايش مـــع الآخــرين، و المدرســـــة المجتمعية، و المدرسة دائمة التعلم. T. دراسة محمد عوض البربري:" تطوير سياسات التعليم العالي في مصر لمو اكبة 


\begin{tabular}{|c|c|}
\hline و أن عولمة السوق وتطـــوير وتكثيــف & الحالية للجامعات المصرية فــي القبــام \\
\hline 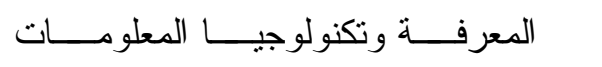 & للتحول مصر إلى اقتصاد المعرفة. \\
\hline و الاتصالات له تأثثير اً كبيراً فى زيــادة & 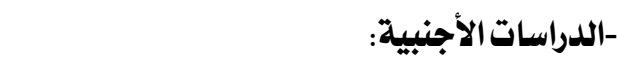 \\
\hline فرص نجاح المنتجات الأوروبية. & ا ـ دراسة مايكل بيترز" ثلاثة نماذج مــن \\
\hline س. دراسة فريدسون سوارز"لغة التواصــل & الخيـــــال فـــــي عـــــر اقتــــــاد \\
\hline بين المعلمين و الطلاب والتعلم التعاوني & 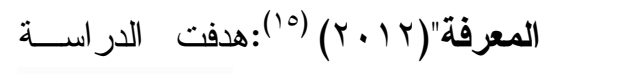 \\
\hline والابتكـــار بولايــــة بريــــــ ووتـــر & إلى التعرف على دور الابتكـــار فــى \\
\hline 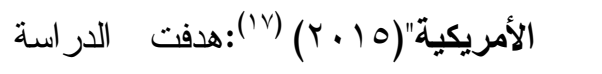 & التعليم العالي وعلاقته باقتصاد المعرفة \\
\hline إلى التعرف على العلاقة بــين المعلــم & بالو لايات المتحدة، واعتمد البحث على \\
\hline و الطالـــب ودور إســـتر اتيجية الـــتعلم & المنهج الوصــفي، وتوصــل إلـــى أن \\
\hline التعاوني في تحسين الابتكاريــــة لــــى & اقتصاد المعرفة وما يحمل من الــسلع \\
\hline طلاب المدارس الثانوية بو لاية بريـــدج & و الخدمات الرقميـــة و الرمزيـــة غيــر \\
\hline ووتر الأمريكيــة، و اســتعان الباحـــ & الملموسة يؤدى إلى الطلــب المتز ايـــد \\
\hline بالمنهج الوصفي، مع ملاحظة ســلوك & على خريجي الجامعات ذوى المهارات \\
\hline المعلمين و استجابات الطلاب المصاحبة & الممتازة، و الذين تتوفر لـــيهم القــدرة \\
\hline لها، وتوصل إلى أن التو اصل و العلاقة & على الابتكار فى المعر \\
\hline الجيدة مع الطلاب وتوفير بيئة من الثقة & r. دراسة ميلوس بارزنين" تأثير الاقتصاد \\
\hline و الدعم النفــــي لهــــــــلال مرحلـــة & القائم علــى المعرفــة فـــي القــدرة \\
\hline المر اهقة بساعد على زيــادة دافعيــتهم & التنافـسية للاقتـــــاديات والأعمـــال \\
\hline نحو التعلم وزيادة إيجابيتهم وقــدر اتهم & التجاريــــة الأوروبيــــة|(1) : هــــــت \\
\hline الابتكارية. & الدراسة إلى التعرف على كيفية التحول \\
\hline ـ ـ دراسة جيكــوب جيفريـز :"دور مــدير & من الاقتصـاد التقليدي نحــو الأنـشطة \\
\hline المدرسة الاككترونية:دراســة بطــرق & و القطاعات القائمـــة علـــى المعرفـــة، \\
\hline 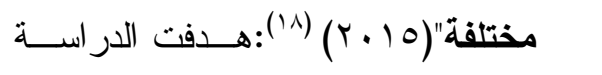 & و اعتمـــدت الدر اســــة علـــى المـــنهج \\
\hline إلى التعرف على دور مديري المدارس & الوصفي، وتوصل إلى أن التحول إلــى \\
\hline الثانوية في تدعيم التطور ات والتعديلات & اقتصاد المعرفة يساعد علـى تحـسـين \\
\hline التكنولوجية التي تم إخالها على التعليم & القدرة التتافسية للاقتصـاد في أوروبـــا، \\
\hline
\end{tabular}


7. در اسة بوستاش مانشى "العلاقــة بــين

التقدم وبعض المؤشرات المـستخدمة

لقياس الاقتصاد القائم على المعرفــة حالة الدول الست بمنظمــة التعـاون

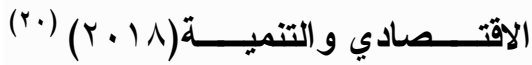

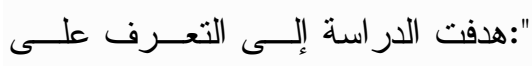

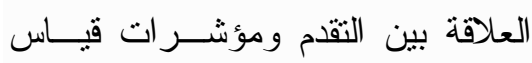

الاقتصاد القائم على المعرفة بست دول

هي الو لايات المتحدة الأمريكية وكنـــدا

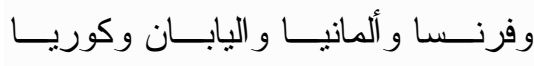

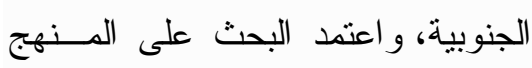

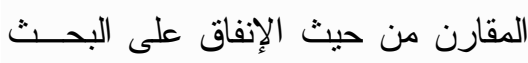

العلمي، وعدد الباحثين، ومنوسط دخل

للفرد، ومؤشر التتمية البشرية، وتوصل وعلدئل

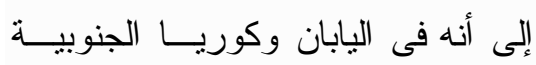

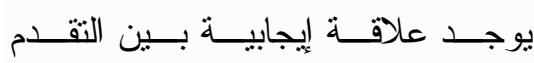

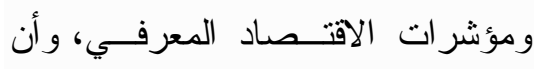

الاقتصاد المعرفي المنطور يعتمد بشكل

أساسي على الابتكار و إنتاج المعرفة.

V. دراسة البنك الدولي" تقرير عن التنمية

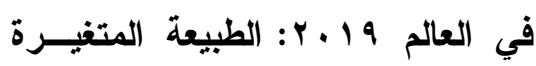

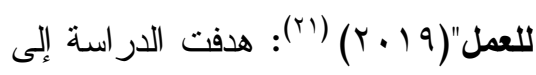

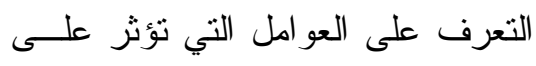
العمل، ودور التكنولوجيا في تحسـين

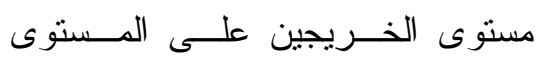
العالمي، و اعتمد البحث علــى المــنهج الوصفي، وتوصل إلى أن التكنولوجيــا لعـيـا
الأمريكي، و اعتمد البحث على المــنهج

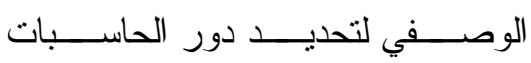
و الثبكات الالكترونية في تحسين التعليم لوني

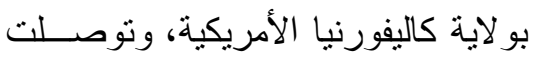

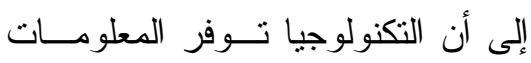

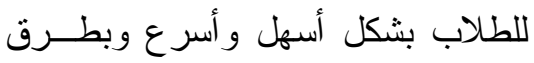

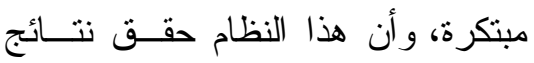

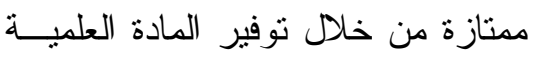

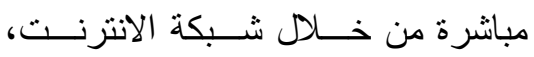

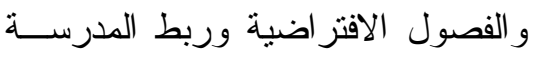

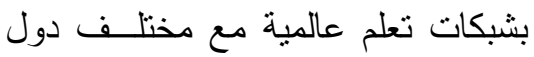

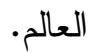

هـ در اســـــة كــــاثرين دوم: "المعلـــــم +

التكنولوجيا = التعلم المختلط بولايـــة كاليفورنيا، ومدى دور المعلم في هذه

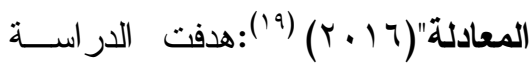
إلى التعرف على المعتقدات و المعارف

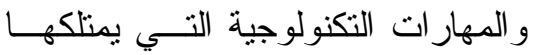

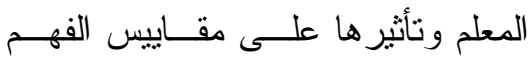

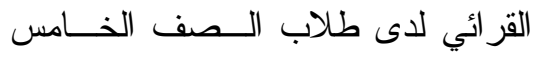

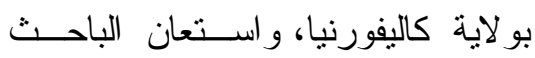

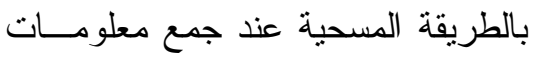

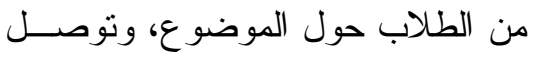

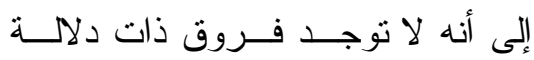
إحصائية بين مخرجات الفهم القرائسي لائي

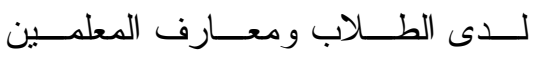
ومهار اتهم التكنولوجية. 


$$
\begin{aligned}
& \text { بيتزز ، ومينوس بــارزنين، ويوســاش } \\
& \text { مانشى، و هذه الدر اسات تتفق مع الدر اسة ومئة }
\end{aligned}
$$

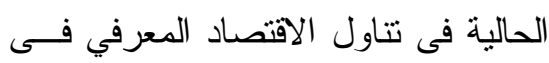

$$
\begin{aligned}
& \text { مصر و الو لايات المتحدة. } \\
& \text { r. تتاولت مجموعة مــن الدراســات دور } \\
& \text { التعليم فى تحقيق منطلبــات الاقتــصاد }
\end{aligned}
$$

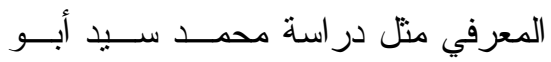

$$
\begin{aligned}
& \text { السعود حيث تتاول دور التعلــيم بـشـكل }
\end{aligned}
$$

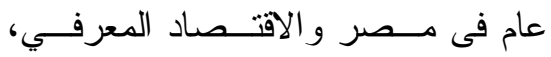

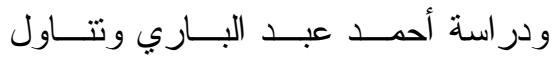

$$
\begin{aligned}
& \text { المدرســـة الثانويـــة العامـــة بفلــسطين }
\end{aligned}
$$

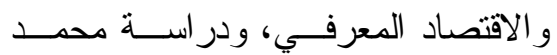

$$
\begin{aligned}
& \text { عوض البربري و الذي تتــاول التعلــيم } \\
& \text { العالي وتحقبـق الاقتــصناد المعرفــي، } \\
& \text { ودر اسة محمد أحمد حسين حيث تتــاول العيل } \\
& \text { دور الجامعــة فــى تحقيـق الاقتــصاد } \\
& \text { المعرفي في مصر وكندا وسنغافورة. } \\
& \text { ع. ـ تتاولــت دراســة البــــك الــدولي دور }
\end{aligned}
$$

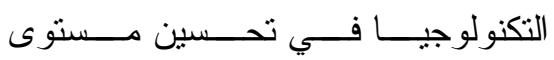

$$
\begin{aligned}
& \text { الخريجين، وتقليل البطالة. } \\
& \text { 0. تختلف الدر اسة الحالية عـن الدر اســات } \\
& \text { السابقة في أنها نتتاول فعالية المدرســة }
\end{aligned}
$$

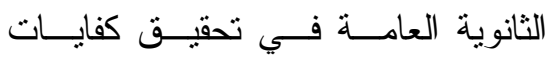

$$
\begin{aligned}
& \text { الاقتصاد المعرفي (دراسة مقارنة بـين }
\end{aligned}
$$

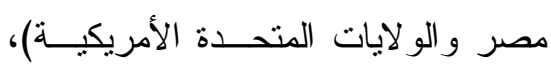

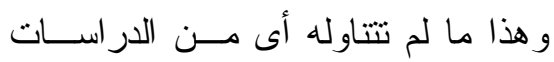

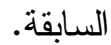


الاقتصادية و الاجتماعية، و هذا يتضمن جلــب

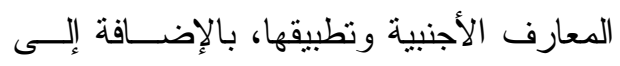

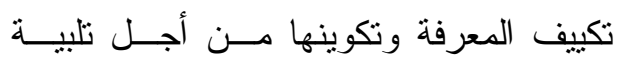
احتياجاته الخاصة (ع r).

ويعرف كذلك على أنه الاقتصاد الذي

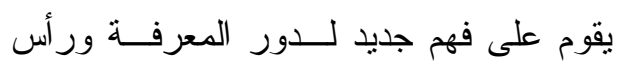
المال البشري في تطوير منظومسـة التعلــيم و التدريب و البحث، مع تطبيق بيئة تقنية تفعل فئل

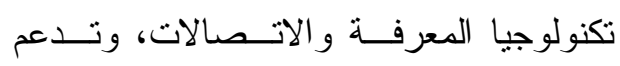

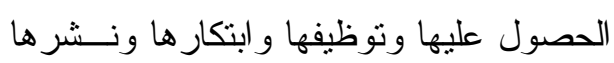
بهدف تحسين نو عية الحياة بكافةمجالاتها (ro). تاسعأ:الإطار النظري للبحث: أ.الإطار العام للاقتصاد المعرفي:

تعتبر المعرفة أحد الأبعاد الأساسية التي

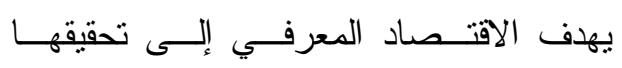

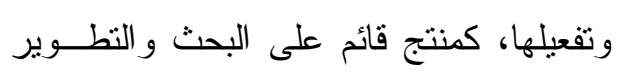

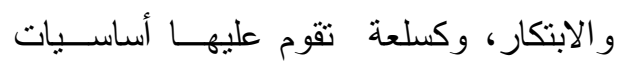

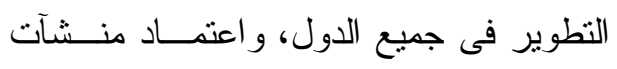

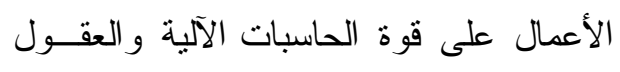

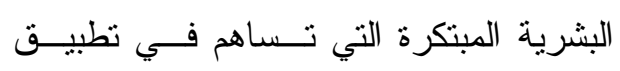
المعرفة في الإنتاج(بَ).

وفكرة قيادة المعرفة للاقتصاد تـشمل

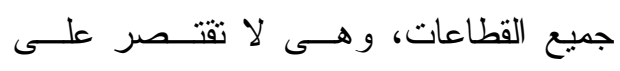

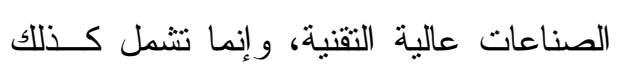

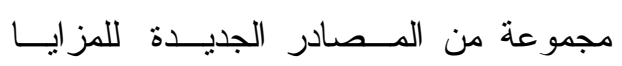

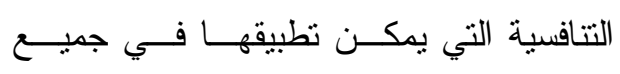

7. تتفق الدراسة الحالية مع در اسة محمــــ

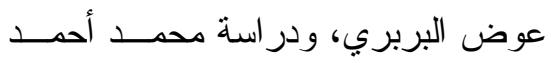

حسين فى الاستعانة بــالمنهج المقـــارن كمنهج للار اسة الحالية.

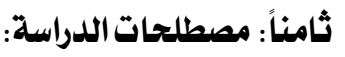

الفعالية:Effectiveness

تعرف الفعالية بأنها الظاهرة التي تقوم

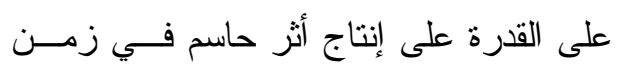
محدد، ويمكن تقييمها في ضو ء وضعاً قائُــاً

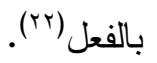

و الفعالية في الدراسة الحاليــة تمثنـل

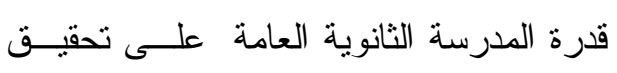

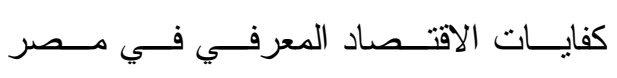
و الو لايات المتحدة الأمريكية. الكفاية:competencies

تعرف على أنها المقدرة التي تـشمل

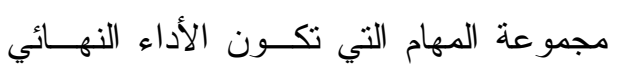

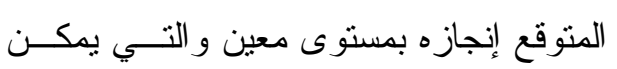
ملاحظتها وقياسها (rr). و الكفاية في البحث الحالي تعنى قدرة المدرسة الثانوية العامة على تحقيق متطلبات الاقتصاد المعرفي بها. الاقتصاد knowledge economy: المعرفي:

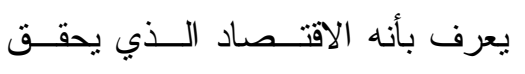
استخداماً فعالاً للمعرفة من أجل تحقيق التتمية 
لأعمالهم، أبي أنه يقدم فرص عمل جديدة لكلأفر اد.

7. تسهيل نـشـر المعلومــات و المعسـارف وتكييفها مع الاحتياجات المحلية وتحويل المعارف العلمية إلى الثكل الرقمي. V. النوازن بين المعرفة و الموارد، وتطوير النظم التعليمية لمواكبه المتطلبات التـي وني وني يفرضها هذا النمط من الاقتصاد.

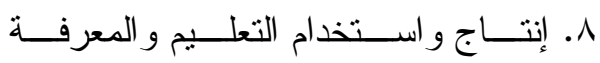
للمساهمة في النمو الاقتصادي.

9. تحول المعلومات و المعرفة إلـى ســلـع يمكن الاتجار فيها وتداولها، فقد أصــبح لها قيمة تبادلية و استعماليه عالية.

• ا. تو افر قطاعات إنتاجية سلعية وخدميــة حديثة، منل الصناعات التحويلية عاليــة

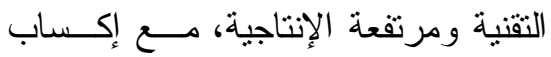
القطاعات الإنتاجية ميزات تتافسية وفتح الإناه آفاق أوسع أمام فرص العمل و النتغيل. عناصر الإتصاد المعرفي: يتكون الاقتصـاد المعرفي من عــدة عناصــر المبني على المعرفة، مع زيادة المساهمة منها:

ا ـ المعارف العلمية: منت المعارف المرتبطة

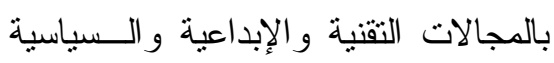
و الاجتماعية و غير ها.

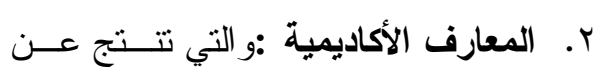
جهات معينة منل الجامعات و المؤسسات
القطاعات، بدءاً من الزر اعة، و التجارة إلـى البر امج الجاهزة و البيوتكنولوجي. ويمكن وصف الإطار العام للاقتصاد المعرفي من خلال المحاور التالية: خصائص الاقتصاد المعرفي:

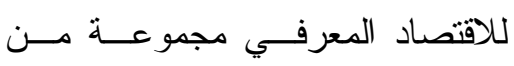

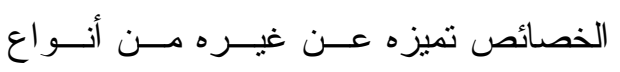
الاقتصاد الأخرى منها ما يلي (rV) ا ـ الاستثمار في الإنسان وحاجاته وتطلعاته بما يتو افق وقدر ات الدولة ورؤينها. r. تــــو افر مـــوارد بــشرية ذات كفـــــاءات

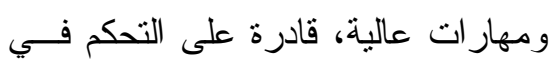

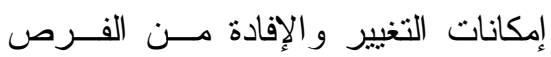
المتاحة . r. أن تكون المعرفة هي المحرك الــرئيس

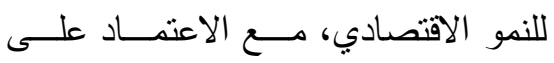
تو افر تكنولوجيات المعلومات والاتصال الاصل و الابتكار . عـ الموارد البشرية ذات المهار ات العاليـــة،

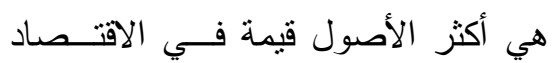
النسبية للصناعات المبنية على المعرفة، وتتمنل في الغالب في الــصناعات ذات التكنولوجيا المتوسطة و الرفيعة. هـ تــــوفير وظـــائف للــــؤهلين معرفيــاً، و المبتكرين، و أصحاب المهار ات الداعمة 


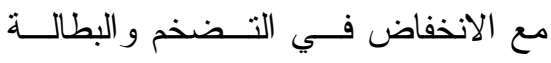
وارتفاع الأجور بشكل ملحوظ(ra).

العناصر و المؤثــرات و الخــصائص

السابقة تشير إلى أن الاقتصاد المعرفي فرصة جيدة ورابحة لتطوير جميع قطاعات الدولـــة

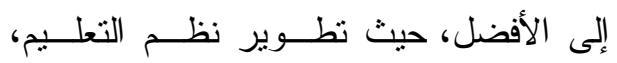
وتحسين مستوى العمالة، وتطوير الخــدمات و المنتجات بالإضافة إلى إكــساب المعــارف الطابع الرقمي مما يمكن من تطوير الدولـــة ككل.

ب.فعالية المدرسة الثانوية العامة بمصر في تحقيق كفايات الاقتصاد المعرفي:

إن إتاحة المعرفة في أي دولة شــرط

ضروري وهــام، بجانــب تطـــوير التعلــيم

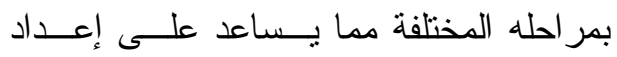

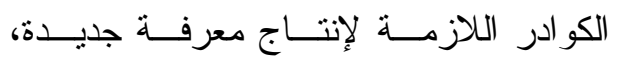
و الاستفادة منها وتحقيق الاستخدام الأمنل لها، لهونا، لذا على الدولة أن تسهل عمليات الاســتخدام

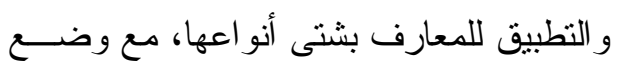

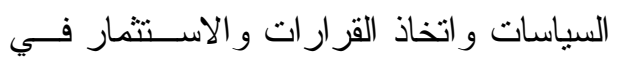
التعليم مما يسهل استخدام المعرفة والابتكــار

$$
\text { فيها (r.). }
$$

ويمكــن اســتعر اض مـــدى فعاليـــة

المدرسة الثانوية العامة بمصر فـي تحقيــق كفايات الاقتصاد المعرفي من خلال المحاور

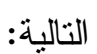

البحثية كرسائل الماجـستير و الــدكتور اه

$$
\text { و الأبحاث العلمية. }
$$

r. المعارف الإعلامية:وهي تختص بإيصال

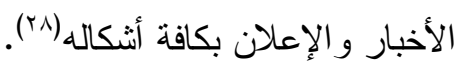
ع. حوامل السلع المعرفية: وهى تتــضمن

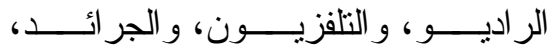
و المجـــلات، و الكمبيــــــز ، و الــــرو ابط الالكترونية كالمجلات ومواقــع النـشر العلمي و الكتب. مؤشر ات الاقتصاد المعرفي: يمكن لأي اقتصاد أن يحمل اســـم اقتـصاد معرفي إذا توافرت فيه المؤشرات التالية: ا. مؤشرات العلم و التكنولوجيا:منل نوافر الأبحاث العلمية على المستوى الدولى.

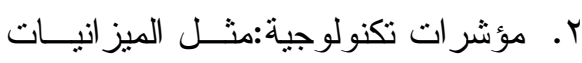

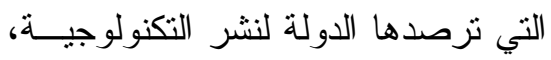
$\ddot{2}$

$$
\text { و التكنولوجية. }
$$

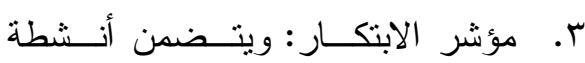

$$
\text { الابتكار العلمي و بر اءات الاختر اع. }
$$

ـ. مؤشر ات تتموية: وتتضمن تتمية الموارد البشرية وتحسين مهار اتها.. 0. مؤشــــر ات معرفيــة: تــشمل نــشر تكنولوجيا المعلومات، و التوعية بأهميتها. 7. مؤشر ات اقتصادية: وهى تعنــى نمــو كبير وملحوظ فى النواحي الاقتــصادية، 


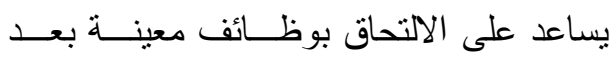

التخرج يؤدى إلى عزوف خريجي المرحلـــة

الإعدادية عن الالتحاق بالتعليم الفني مما يزيد

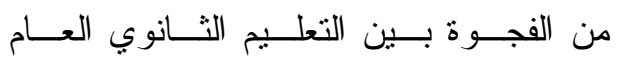

و الفني (rr).

ثانياْ:الإدارة المدرسبة:

من الملاحظ أن هناك بعـض أوجـهـ

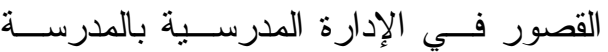

الثانوية العامة و التي لا نتتاسب مع منطلبــات

الاقتصاد المعرفي و التي من أهمها:

ا ـ نقص وعى مديري المدارس بالأســاليب الئ

الحديثة فى مجال الإدارة المدرسية.

r. وجود قدر ات قيادية محدودة مفتقرة إلى الإبداع

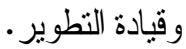

r. ضعف التطوير الملموس فــي العـاملين

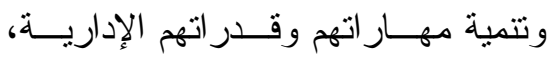

يو ازي التجديدات و التغييـــــات الحادثـــة

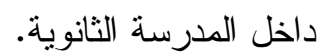

ـ ـ شـــوع الــروتين الـــوظيفي و النــــاذج

و الإجراءات الروتينية التي تعوق ســير العمل داخل المدرسة("r).

0. بعدها عن مجرى النطــور فـي علــوم الإدارة و التكنولوجيا الجديدة.

7. قصور ها عن مو اكبة التطور ات الحادثـــة

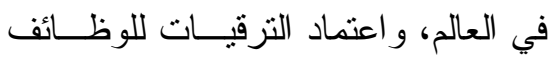

أولاً:السياسات التعليمية بالتعليم الثانوي:

يقصد بها تحديد الشكل العام لمرحلـــة

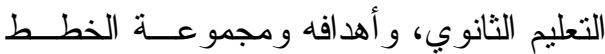

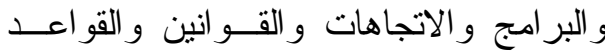

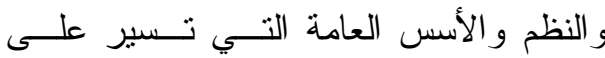

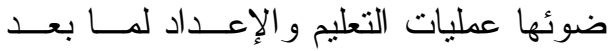

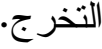

ومن الملاحظ ضعف ارتباط السياسة

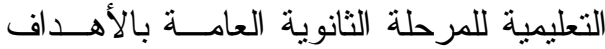

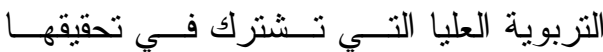
مؤسسات ووزار ات أخرى مع وزارة التزبية و التعليم، بحيث تعتمد على رؤية و إستر اتيجية و واضحة تقوم على بلورة الـسياسة التربويـــة

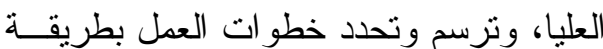
إجرائية، وبالتالي فــإن الــسياسة التعليميــة بالتعليم الثانوي العام غير واضـــة بــشكل كبير (r) و التعليم الثانوي العام رمــز للتميــز

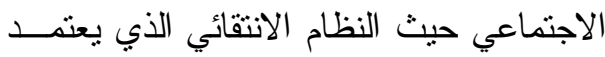
على مجموع الدرجات يعزز فكرة أن التعليم الفني يتيح لخريجيه الأقل حظاً فرصاً وظيفية ومهنية متوسطة، مع دعم التباين و التمايز بين

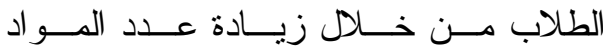
الاختيارية مقارنة بالمو اد الإجبارية. و اعتماد الثهادة الثانوية كمعيار وحيد للالتحاق بالتعليم الجامعي يؤدى إلى الاهتمام بانتشار التعليم النظري وتوسعه نطاقه، مــــــا 
r. المناهج تقوم على التلقين الــذي يلغــي

العقل ويرسخ الرؤية القاصرة.

ــ انتشار الدروس الخصوصية، حيــث إن إن

الامتحانات تتـسم بالتتافسية الــشديدة

فتصبح الدروس الخصوصية هى الملاذ

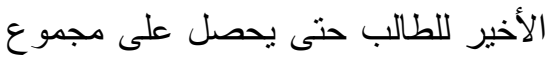

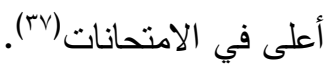

رابعاً:نظم المعلومات والاتصالات:

تم توفير وحسـدة لــنظم المعلومــات

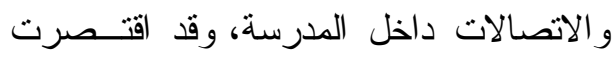

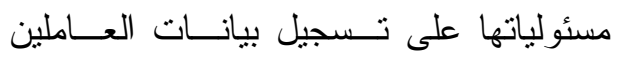

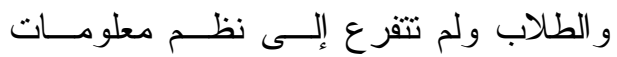
إستر اتيجية، وتتفيذية، ومالية، ومعرفية، وهو

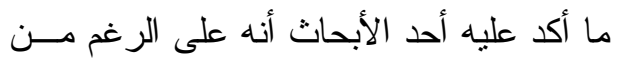

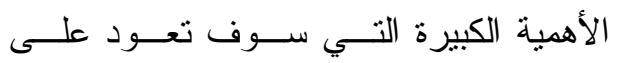

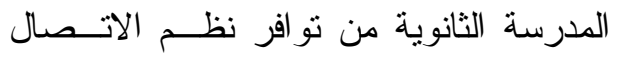
و المعلومات الفعالة داخلها إلا أن هذه النظم لم

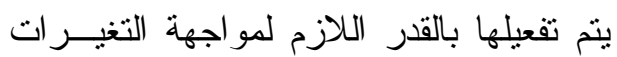

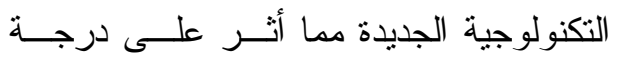
الاستفادة منها (r) .

وبالرغم من ازدياد المعرفة و التطــــور

التكنولوجي، وتوظيف الكومبيوتر وتكنولوجيا

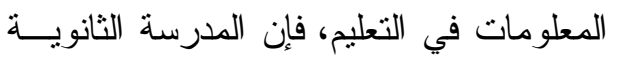

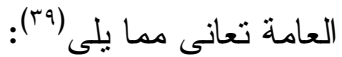

ا ـ ضعف نو افر شبكة معلومانية للعـاملين

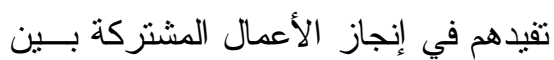

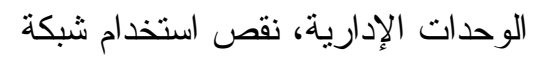$$
\text { الإنترنت في الاتصالات الداخلية. }
$$

القيادية و الإدارية على الأقدمية المطلقـــة

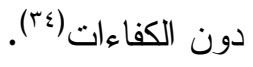

ثالثاً: المناهج الدراسية:

مع بداية الألفية الجديدة، والتي تتـسم

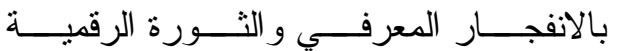

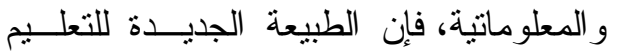
تقرض استخدام مناهج وأســاليب تدريسـية تركز على التعلم الفعال، مما يعنى تحول دور

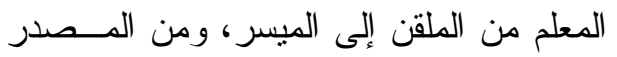
الوحيد للمعلومة إلى مــدير لحلقــات الــتعلم ومدرب إلكتروني (ro)

وقد شهر التعليم الثانوي العــام فـي

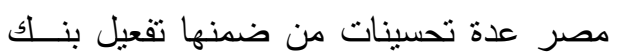

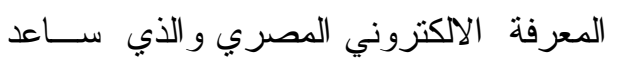
على الوصول إلى المعارف الأكثتر حداثـــة

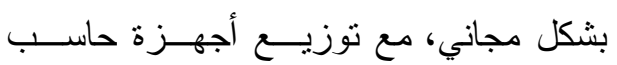

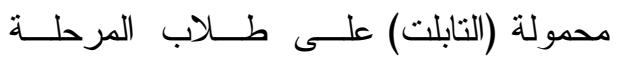
الثانوية حتى يمكن الوصول إلى المعلومــات

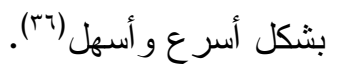
وبالر غم من الجهود المبذولة لتطــــير

المدرسة الثانوية العامة فإن الفجوة المعرفية، تزجع إلى الأسباب التالية:

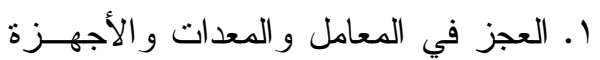
خاصة الحاسبات الآلية وكذلك المر اجـع بالمكتبات المدرسية. r. ترسيخ فكرة الترفع عن العمل اليـدوي

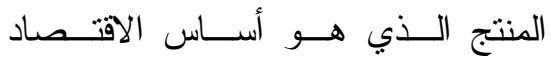
المعرفي. 
فيها، وبالنظر إلى الابتكار بالمدرسة الثانويــة العامة يلاحظ ما يلي (1):

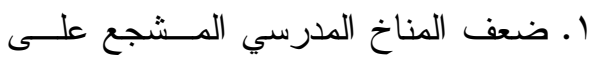

الإبداع و الابتكار داخل المدرسة الثانوية.

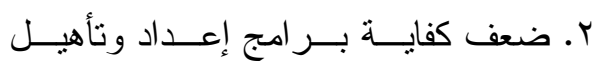

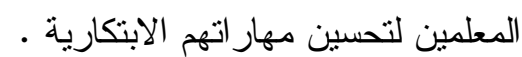

r. المناهج محشوة وتتجاهل عقلية المــتعلم، وتخلق ثقافة الحفظ على حساب التفكيـر

$$
\text { الابداعى الناقد. }
$$

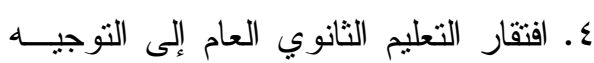

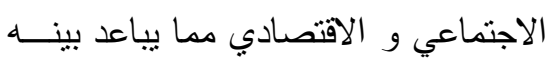

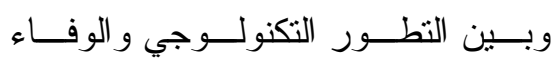

بمتطلبات الاقتصاد المعرفي .

كل هذا أدى إلى ضعف دور المدرسة

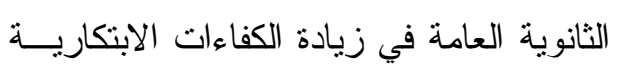

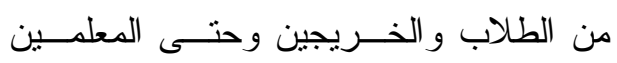

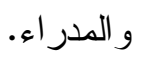

سادساً:الثر اكة مع المؤسسات البحثية:

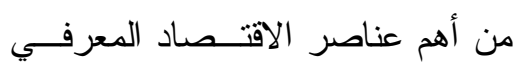

إقامة شر اكة ناجحة مع المؤســــات البحثيـــة

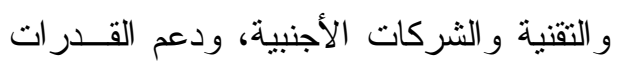

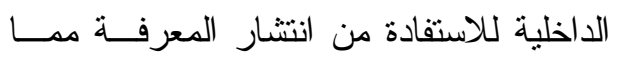
يزيد من الانفتاح على العالم الخارجي(rاء). وقد بين برنامج الأمم المتحدة الإنمائي أن هناك ضعف في تبادل المعلومــات بــين الدول العربية ومن ضمنها مصر ، و إهـــال

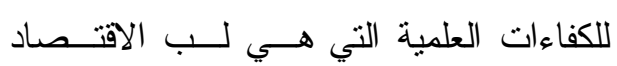

r. افتقاد المدرسة الثانوية العامة القدرة على

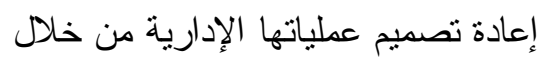
استخدام تكنولوجيا المعلومات.

سـ المدرسة الثانوية العامة لا يتــــو افر بهــــا أجهزة حاسب بــالمختبر ات و القاعـات الدر اسية بشكل كافي.

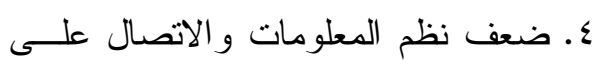

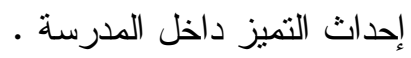
هـ نقص وجود نظام حديث ومطور لحفــ إحلـ

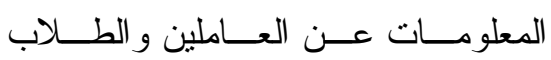
بالمدرسة الثانوية العامة .

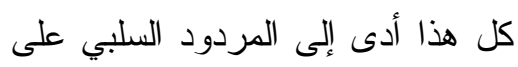
إحداث التجديد الذاتي للمدرسة الثانوية والذي لي الثي تعد نظم المعلومات و الاتصال أحد المتطلبات الأساسية فيه، و أحد أساسيات تحقيق الاقتصاد

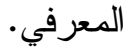
خامساً::التعلم الابتكارى : من أهم مؤشـــرات الابتكــــار علـى الابكى

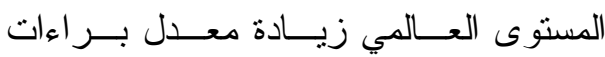

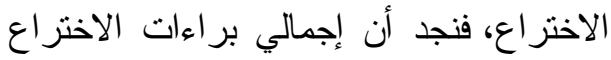

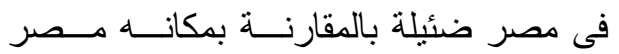

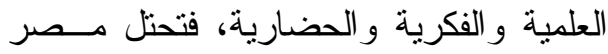
المرتبة V9 من ضمن • با دولة في مجـال

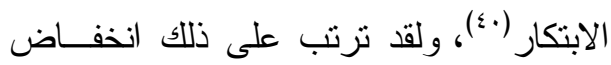
معدلات التصدير الخارجي.

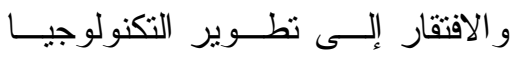
و أثنكال الإنتاج انعكس على نسبة الصادرات

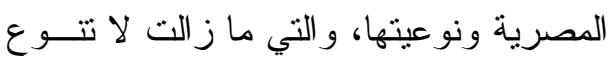


التعليم- باعتباره مــصنع لإنتــاج المعرفـــة

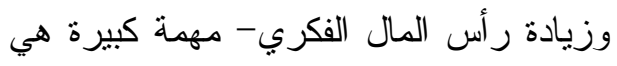

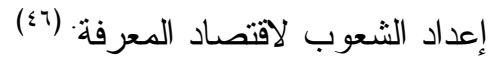

وقد تم تخصيص وحدة تسمى الوحدة

المنتجة بالمدارس الثانوية العام بمصر بهدف

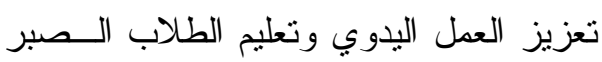
وتحمل المسئولية وتقدير العمل التعاوني، مع لئي

ربط مفهوم التعليم و المناهج بالبيئة المحليـــة و احتياجات المجتمع بأسلوب غيــر تقليــدي،

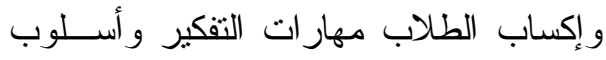
حل المشكلات بطريقة عملية .

ولكن يلاحظ على الوحدة المنتجة ما يلي (v)؛

ا ـ ضعف وضوح الأهداف التربوية للوحدة

لدى المديرين و المعلمين و الطلاب.

r. اللوائح التتظيمية داخل المدرسة تحد من ون ولهين

$$
\text { الابتكار و الإبداع داخل هذه الوحدة. }
$$

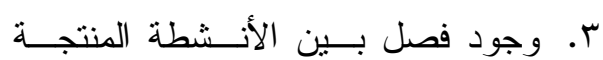

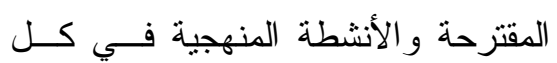

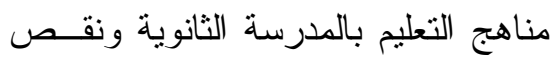
التزويج إعلامياً لهذه الوحدة.

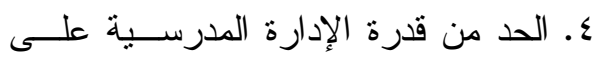
الاستغلال الأمتل لإمكانيات هذه الوحسـدة الإندان

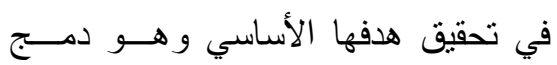
الجانب الأكاديمي بالمهني للطلاب.

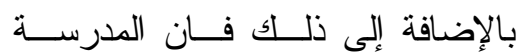

الثانوية العامة في مصر منفصلة عـن عــالم العمل و الناجم عن ضعف تفاعلها مع منظمات

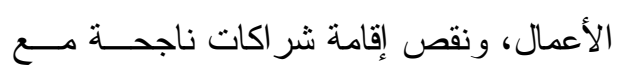

المعرفي، وكذللك غياب إستر اتيجية صــناعة

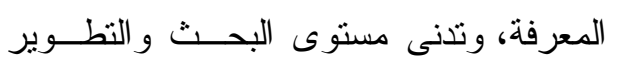

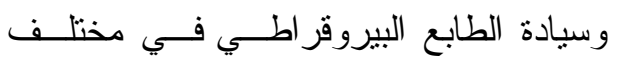

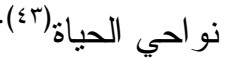

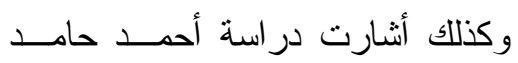
نقادي إلى ضعف الــشر اكات الفاعلـــة بــين التعليم الثانوي العام في الدول العربية بــشكل عام وفى مصر بشكل خــاص و المؤسـسـات البحثية و الثركات الأجنبية، وهذه المؤسسات لها دور كبير في تحسين مستوى خريجي هذه

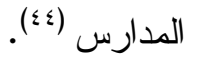
سابعاً:الارتباط بسوق العمل: يو اجه الاقتصاد المــصري، تحـديات

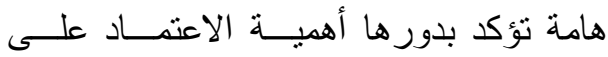
المعرفة كأهم محرك للنمو الاقتصادي، ويأني

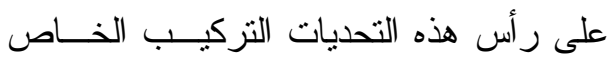
بالسكان، حيث تبلغ نسبة السكان من الثباب-

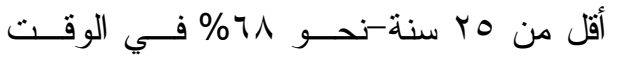

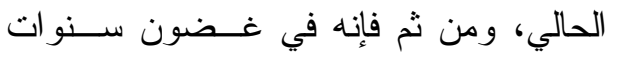

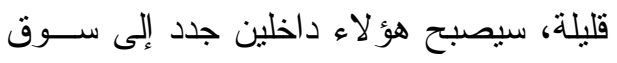
العمل، يحتاجون فرصا للتوظيف ويطدحسـون في مستويات عالية من الأجور (؛؛).

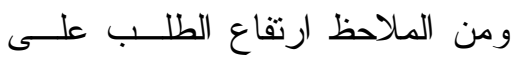
الأيدي العاملة المتخصصة عالية المهارة في

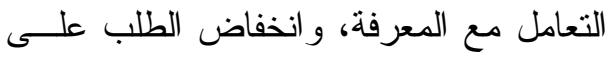
العمالة غير المتخصصة، مما يؤثر في هيكلة

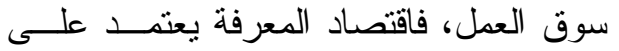

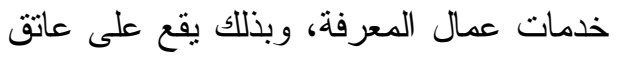


على إيجاد مناخ من الثقة بينها وبين الأســرة

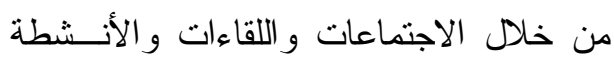
المختلفة(0).

وبعد اســتعر اض فعاليــة المدرســة

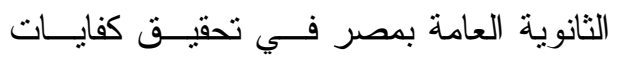

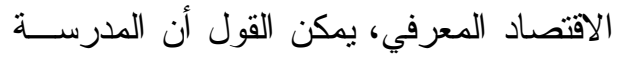

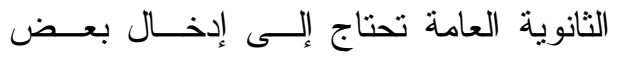

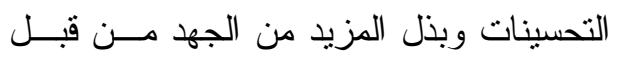

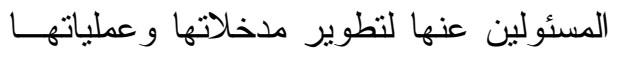

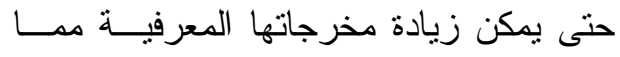

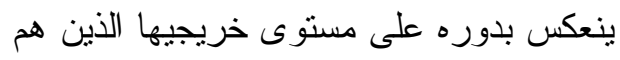

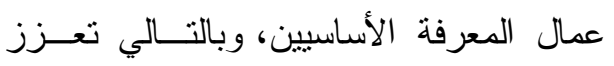

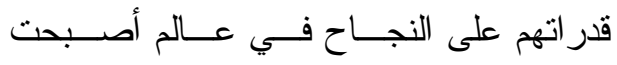
المعرفة فيه هي أساس التقدم.

ج. فعالية المدرسة الثانوية العليا بالولايات

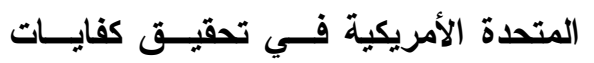
الاقتصاد المعرفي:

تحتل الو لايــات المتحـــدة الأمريكيـــة المركز السابع على مستوى العالم في مجــال

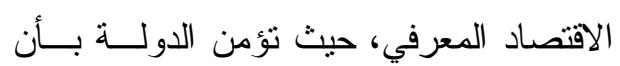

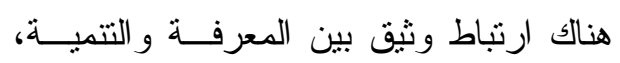
ونتيجة لتبنى الدولة بـشكل كامـل لــسياسة

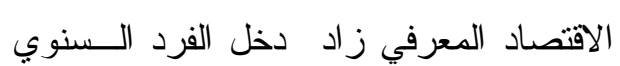
لحو الي( • ألف دو لار أمريكي.

و لأن أهم أساسيات الاقتصاد المعرفي

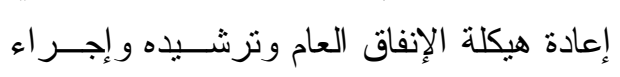

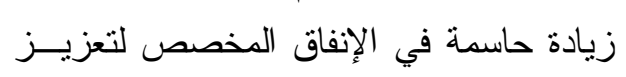

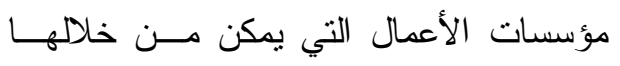

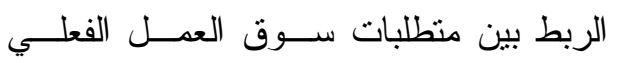
ومهار ات الطلاب بالتعليم الثانوي. ثامناً:العلاقة بين المدرسة والمجتمع:

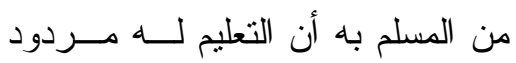

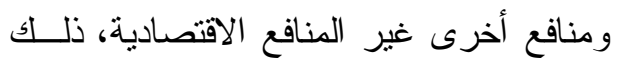

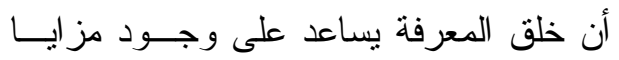

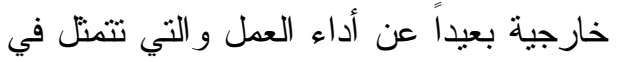
زيادة العلاقة بين أطر اف المجتمع، وزيــادة التماسك الإجتماعى، و المساهمات المجتمعيــة الناجحة، وبالتالي تصبح المدرســـة مركــزاً لتدعيم تماسك أعضاء المجتمع. ويوضح الو اقع أن المدرسة الثانويـــة العامة تفتقر لقنوات اتصال فعالة بين الطلاب

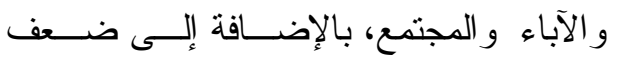

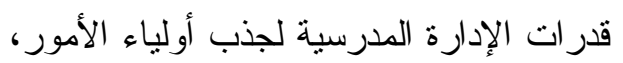
وتفعيل دور هم في تعليم أبنائهم (^§). ومن الملاحظ غياب العقد الاجتماعي

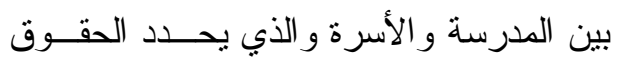

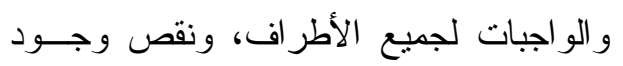

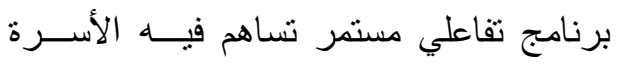

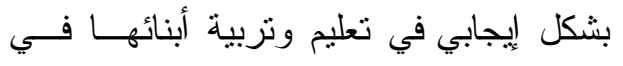
المدرسة، وضعف بر امج التوعية المـستمرة

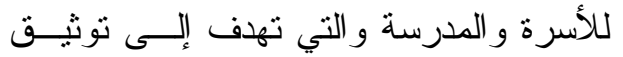

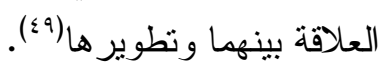
وكذلك لا يوجد بالمدرســة الثانويــة

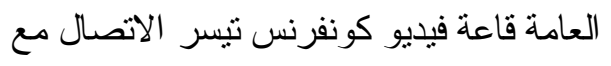

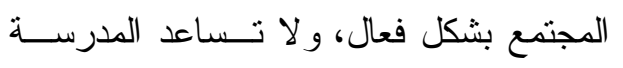


عائق في ظهور شكل عام ومحــد للنظــام

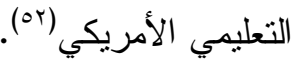

ويتم التـريس في معظــم الــصفوف

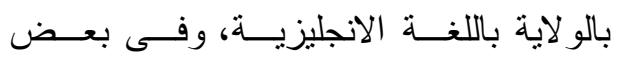
المدارس والتي يكون بها كثافة طلابية عالية

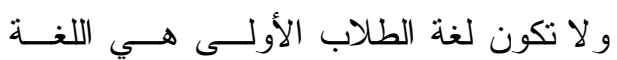

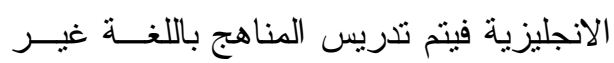

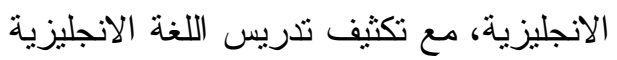

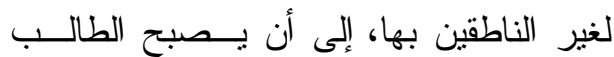

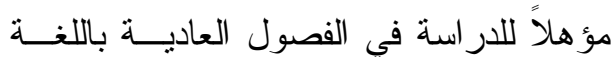
الانجليزية(م) هلان

وتحنل مدارس بوسطن الثانوية العليا،

ومدارس سان دييجو مكانـــه مرموقـــة بــين

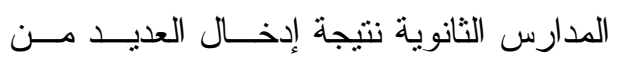

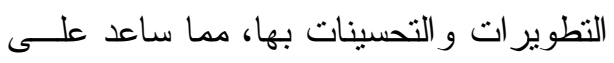

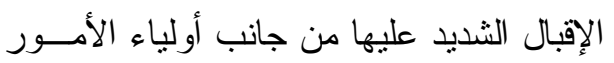
و الطلاب المحليين و الو افدين (؛ْ). ثانياً: الإدارة المدرسية:

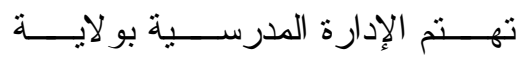
كاليفورنيا بتوظيف تكنولوجيــا المعلومـــات، حيث تؤمن أن فثل عمليــة إدارة المدرســـة يرجع إلى عاملين أساسيين هما: المــشكلات

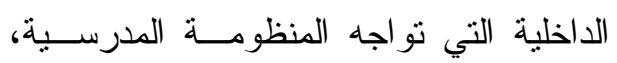

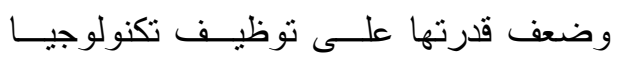
المعلومات(00).

وتعمل الإدارة المدرســية بالمدرســة

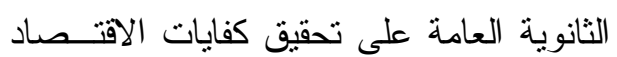
المعرفي من خلال ما يلي:
المعرفة، ابتداءً من المدرسة الابتدائية وصولاً

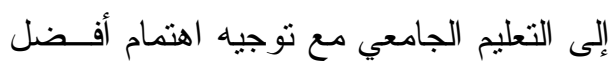

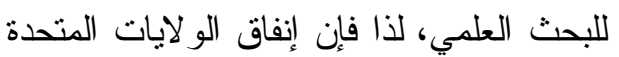

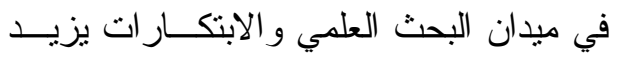

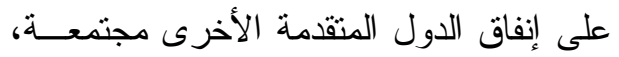
ما يساهم في جعل الاقتصاد الأمريكي الأكثر

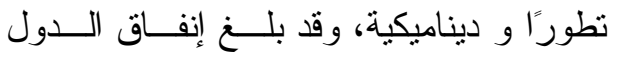
الغربية مجتمعة في هذا المجال ـ . 9 مليــار

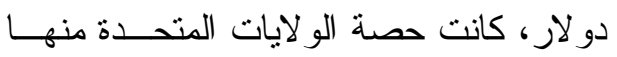

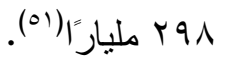
والخبرة الأمريكية في مجال الاقتصاد

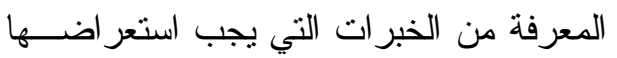
في هذا المجال، نتيجة للمركز المرموق الذي لئي وصلت إليه الولايات المتحـــدة فــي مجـــال

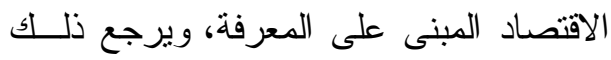
إلى اهتمامها بتطوير التعليم كعامل أساسـي لهي

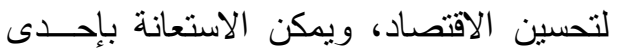
النماذج الأمريكية الناجحة في تحقيق التعلــيم

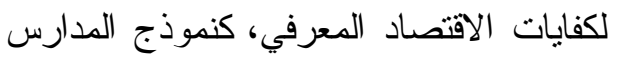

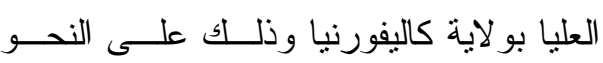

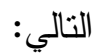
أولاً:السياسات التعليمية بالتعليم الثانوي: نتيجة إتباع الو لايات المتحدة الأمريكية

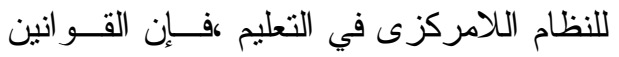

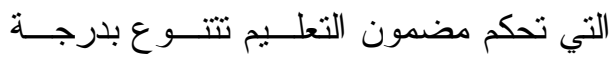

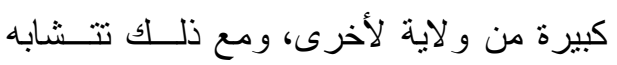

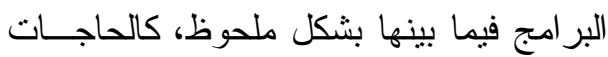

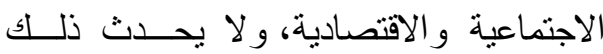




$$
\begin{aligned}
& \text { و الكتابة و التفكير داخل الفصول ســواء } \\
& \text { ا ـ ركزت الإدارة المدرسية بهذه المــدارس } \\
& \text { بمفردهم أو في مجمو عات صغيرة. }
\end{aligned}
$$

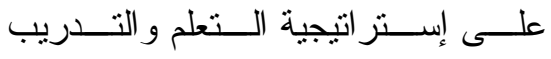

$$
\begin{aligned}
& \text { التعاوني. } \\
& \text { r. إتاحة الوقت الكافي للمعلمـين لتـدوين }
\end{aligned}
$$

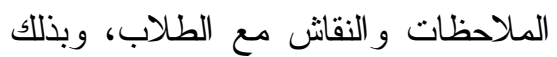

$$
\begin{aligned}
& \text { مما يمنح الطلاب الشعور بالثقة و الانجاز } \\
& \text { ويمدهم بمهار ات أفضل في التعلم. } \\
& \text { r. الحرص من قبل هيئة التعــــيم بالو لايـــة } \\
& \text { على وضع مناهج نقابل تعدد الثقافات في }
\end{aligned}
$$

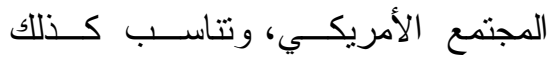

$$
\begin{aligned}
& \text { المطالب القانونية و التـشريعية، وتلبــى الانس } \\
& \text { احتياجات كل طالب، مع دمج القيم الخاصة } \\
& \text { بالمدرسة وتحسين مهار ات المعلمين. } \\
& \text { ومن مظـــاهر التطـــوير بالمـــارس } \\
& \text { الثانوية العليا بو لاية كاليفورنيا إعادة ربط هذه } \\
& \text { المدارس من خلال شبكة عمل يمكـن مــن } \\
& \text { خلالها تبادل الخبر ات و المعلومات مما يساعد } \\
& \text { على تتمية مهار ات الطلاب وزيادة اعتمادهم } \\
& \text { على أنفسهم في عملية التعليم و التدريب(ه). } \\
& \text { من الملاحظ أن المنــاهج الدراســية ولثية } \\
& \text { بو لاية كاليفورنيا تز اعى قدر ات و اســتعدادات }
\end{aligned}
$$

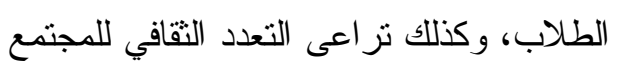

$$
\begin{aligned}
& \text { الأمريكي، مع إعطاء جميع الطلاب الحريــة } \\
& \text { للتعلم كل" حسب قدر اته ومهار اته. } \\
& \text { رابعاً:نظم المعلومات والاتصالات: }
\end{aligned}
$$

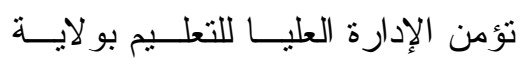

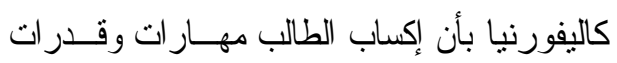

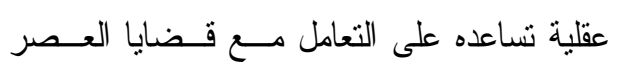

$$
\begin{aligned}
& \text { قد تعوق تحقيق جودة العمل. } \\
& \text { إلكترونياً( (ov) }
\end{aligned}
$$


البيانــات ونظـــام المعلومـــات إلـــى شــــــة المعلومات، و الاستفادة من شبكة الاتصالات، وتفعيل تكنولوجيا الاتــصالات فــي عمليــة الإدارة مما يساعد على أن يصبح كـلـل فــرد مسئولاً عن اتخاذ القرار (·").

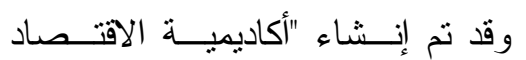
و الأعمال" بالمدارس الثانوية العليـــا بالو لايـــة و التي تهدف إلى دمج التكنولوجية في المناهج بالإضـافة إلى أنها تقـــدم بــر امج تكنولوجيــا المعلومات المتقدمة، ومن ثم فإن طلاب هذه الأكاديمية يتعودو ا على استخدام التكنولوجيــا في كافة البر امج الدراسية. خامساً:التعلم الابتكارى:

يهتم التعليم التُــانوي العــام بو لايـــة كاليفورنيا بتتمية التعلم الابتكارى، مع التزكيز على أسلوب حل المشكلات، وحث المعلمـين للطلاب على التفكير النقدي.

كذلك يتم تعزيز إنجاز الطلاب وســـ

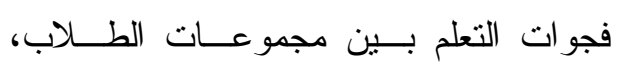

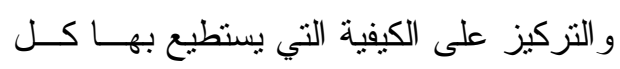
طالب أن يحقق مستويات عالية من الــتعلم، ونتمية بيئة تعلم متفردة لكل طالب، و الاهتمام

بأنشطة يو مية مبتكرة.

وبمساعدة المستشنار الأكــــاديمي فـــان

الطلاب يقومو ا بتصميم خطة در اسية تكــون

متتاسبة مع اهتماماتهم ومـــو اهبهم الخاصـــة
أصبح ضرورة من ضروريات الحيــاة، وبخاصـــة

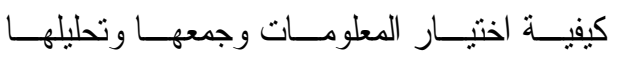
وتفسير ها، وتوظيفها التوظيف السليم، وكذلك تتمية

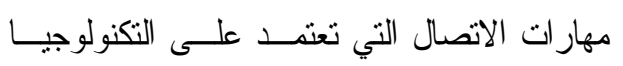
الحديثة، مما يساعد على غرس مهارة التعلم الذاتي

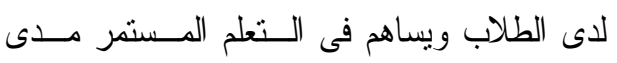

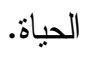

وكذللك يبنى التعليم بالمدرســة علـىى

النظام المفعل بالتكنولوجيا، والذي يعتمد على

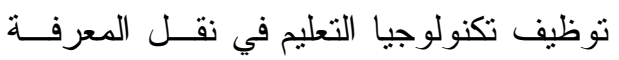
وتوصيلها للطلاب، وبناء نمــوذج مرجعـي لتدعيم استخدام النمذجة و المحاكاة في عمليــة

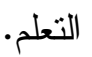

وكـــللك يــتم اســتخدام تكنولوجيـــا المعلومات في العمل المدرسي كأهم مقومات النجاح، و استمر ار ها فهـي مــن الــرورات الأساسية لتطوير النظم التربوية و التعليمية وتحسين الجو انب المختلفة للتعليم. ويتم تحفيز المدارس بولايـــة كاليفورنيــا

لتصبح مدارس مستقلة ذات تكنولوجيا عاليــة

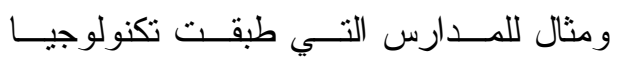

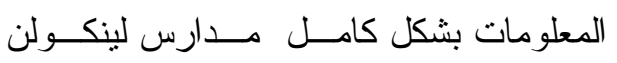

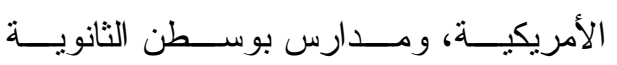
العليا(ه9).

ويتم تفعيل التعلم من خلال الاعتمــاد على الإنترنت و البريد الإككروني و المصادر

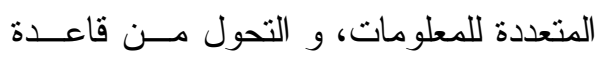


إعدادهم للجامعة بالإضــافة إلــى تعلـــيمهم

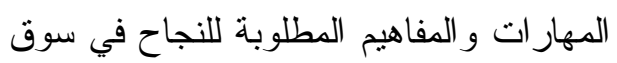

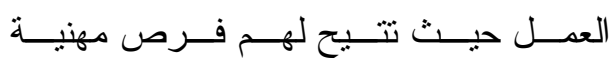
منتو عة (؟ (7)

ومن مظاهر اهتمام الولاية بإعداد الطــلاب لسوق العمل ما يلى:

1. إقامة شر اكة مع المؤســسات الإنتاجيــة

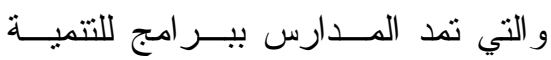

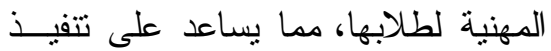

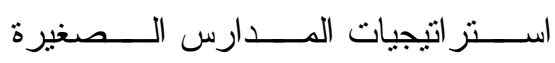
و المتمركزة حول تصميم المــنهج طبة

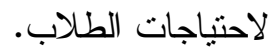

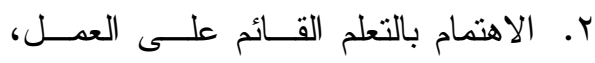

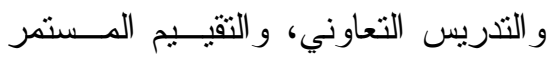
لخبرات العمل لاى الطلاب، ومثال لذلك ولن مدارس بوسطن الصغيرة و التي أقامــت

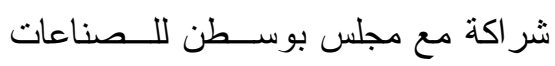

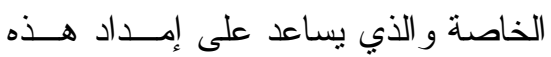
المدارس بفرص تدريب مكثفة للطلاب. ب. إقامة مركز للتعلم التعــاوني بالمــدارس

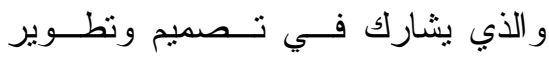

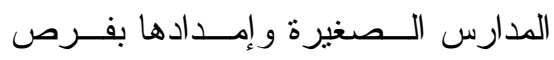
التتمية المهنية(70).

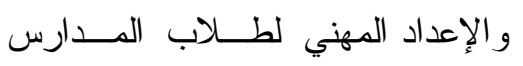

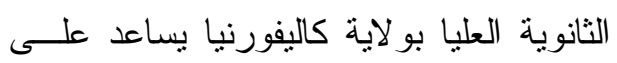

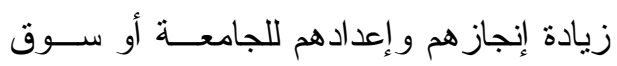

وهو مــا يغــرس فـيهم مهــار ات العدــل

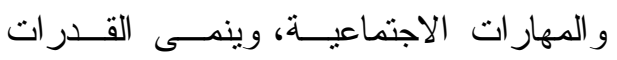
الإبداعية و الابتكارية لديهم (1). سادساً:الثر اكة مع المؤسسات البحثية: تقوم المدرسة الثانوية العليـــا بو لايـــة كاليفورنيا بعمل شر اكة مع المؤسسات البحثية و التي من شأنها در اسة بيئة المدرسة ومحاولة لئة

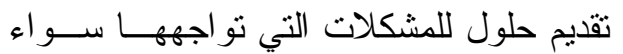
كانت مشكلات داخلية مرتبطـــة بــالمعلم أو لون

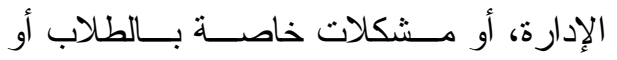
مشكلات سلوكية ناتجة عن هـــه المرحلــة الحرجة(Tr).

ومثنال للمدارس التــي تقـــوم بعدــل شر اكة مع مر اكز بحثية"مــدارس التحــدي"

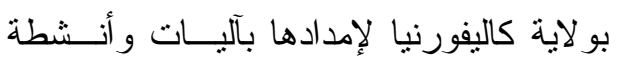
لتحسين تعلم الطلاب، وتتمية الكفايات المهنية للمعلمين و الوصـــول مـــع أوليــاء الأمسـور

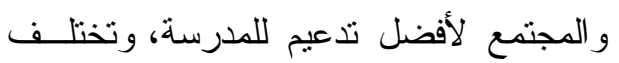

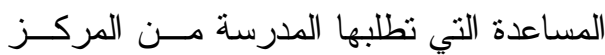
البحثي حسب طبيعة المشكلة مادية أو سلوكية أو اجتماعية(T). سابعاً:الارتباط بسوق العمل: يتم إعداد الطلاب للنجاح في عملهـ المستقبلي من خلال برامج عمل تدريبية تدمج الطلاب وتشركهم في الأعمال، وتهتم الولاية

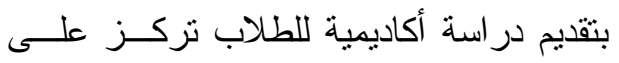


ـ. تدعيم مشاركة أولياء الأمور و أعـضـاء هيئة التدريس بالجامعات ورجال الأعمال

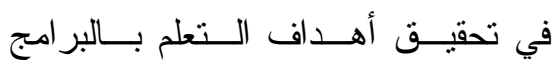
الأكاديمية التي تقدم للطلاب(ه^).

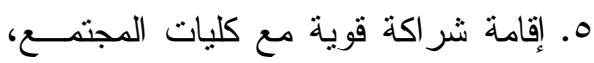
يساعد على تحسين مستوى الطالب الذي

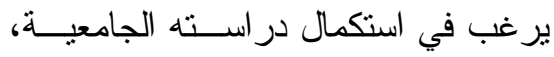
ويعطي كذللك دعم قوى لهذه المــدارس وفي نفس الوقت يعمل على تحسين جودة الخريج(79).

و التدعيم الفعلي الذي تقدمه مؤسسات

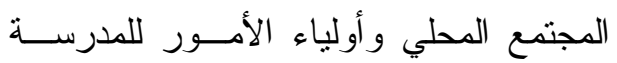

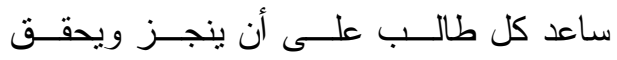

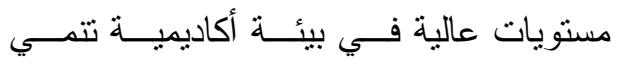
مهار اته وكفاياته، مع تطبيق الاســتر اتيجيات

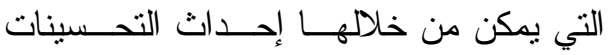
المستمرة في أداء المدرسة. التحليل المقارن:

بعد استعر اض خبرة مصر و الو لايات

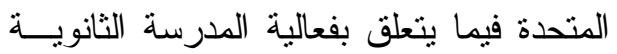
العامة في تحقيق كفايات الاقتصاد المعرفـي لفي لفئي

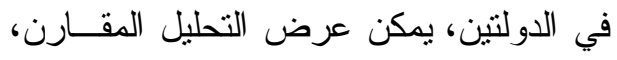
وتتضمن المقارنة المحاور التالية: أولاً. السياسات التعليمية بالتعليم الثــانوي التهاريه

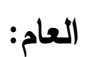
أوجه التشابه: يوجد عدة نقاط توضح

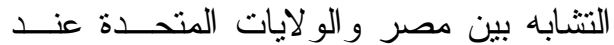

العمل، مما يساعد على زيادة الطلـبـ علـى خريجي هذه المدارس، وتتمية قدر اتهم العقلية و الاجتماعية بدرجة كبيرة، ويكونوا قـادرين

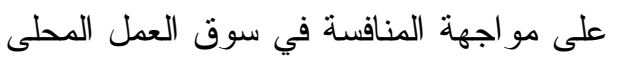
و العالمي. ثنامنا::العلاقةة بين المدرسة والمجتمع: من مظاهر الهتمام المدارس الثانوية العامــة بإقامة علاقة مع المجتمع ما يلي:

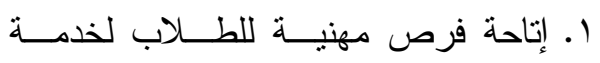

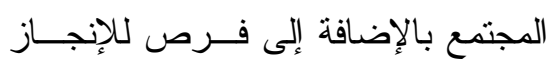

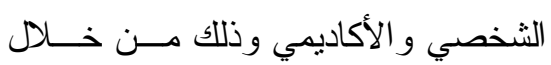
إنشاء ما يسمى "أكاديمية الخدمة الخاصة"

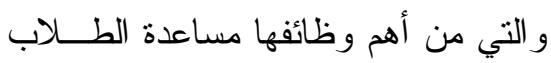

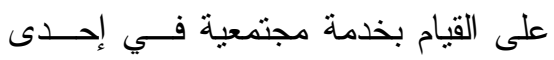
المؤسسات طبقاً لرغبات كل طالب. r. تقديم الطلاب خدمات تساعد في تتميــة

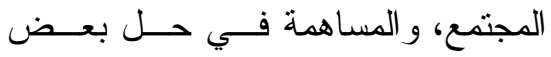
مشكلاته، كالخدمسـة فـي إحسـى دور

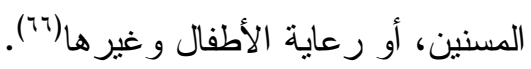
r. مــشاركة المجتمــع و أوليــاء الأمــور و الطلاب في تحسين الخطــــ الدر اســـية

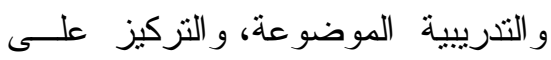
التدريس الابتكارى من خلال بيئات تعلم صغيرة تستعين بير امج شر اكة إبداعيــة هلئة

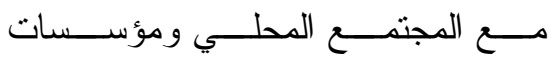

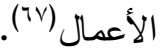


يمكنه بناء الاقتصاد المعرفي في مــصر

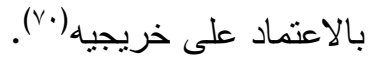

ثانياً: الإدارة المدرسية:

أوجه التشابه: تتشابه مصر و الو لايات

المتحدة في مجــال إدارة المدرســـة الثانويـــة

العامة ويتضح ذلك مما يلي:

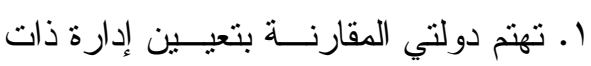

خبر ات و اضحة في مجال التعليم.

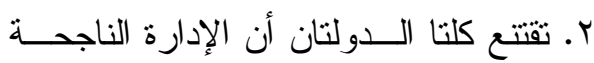

تؤدى إلى بناء طالب ناجح ومعلم ماهر ،

وتهتم كذلك بإدارة العلاقــات الإنـسـانية

داخل المؤسسة.

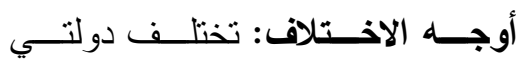

المقارنة في مجال إدارة المدرســـة الثانويــة العامة ويتضح ذلك على النحو التالي:

ا. تهنت الإدارة المدرسية في مصر بتطبيق

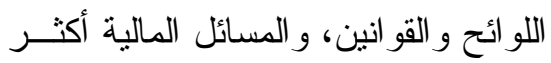

من اهتمامها بالابتكار في العمل، وهــــا

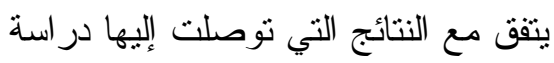

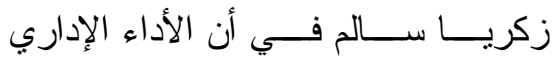

بالمدارس الثانوية العامة بمصر يحتــاج

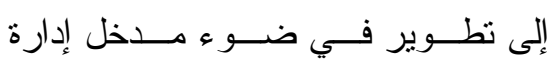

$$
\text { المعرفة (V) (V) }
$$

r. في الولايات المتحدة تهنم الإدارة بتطبيق

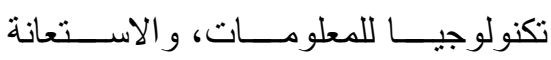

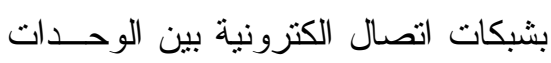

وضع السياسات التعليمية بــالتعليم الثــانوي العام منها ما يلي:

ا ـ تهتم الدولتان بوضع السياسات التعليميـــة

التي تحدد قو اعد التعليم الثانوي العام.

r. تقتتع مصر و الولايات المتحدة بضرورة

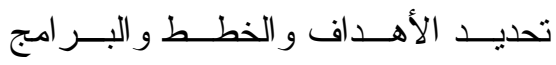

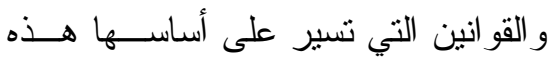

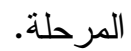

أوجه الاختلاف: يوجد عدة اختلافــات

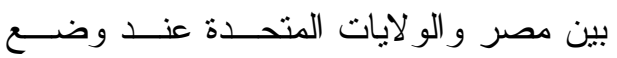

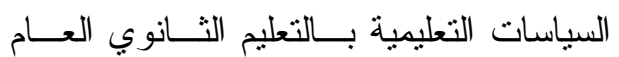

ويتضح ذلك من خلال النقاط التالية:

ا ـ في الولايات المتحدة بالرغم من اختلاف

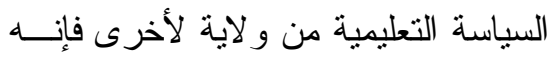

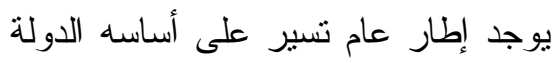

ككل.

r. في مصر هنالك انفصال بين الــسياسات

التعليمية الموضوعة والأهداف المرحلية

المطبقة في الو اقع، مع غموض السياسة

التعليمية للتعليم الثانوي العام.

r. في مصر يتم الاهتمام بالتعليم النظـــري

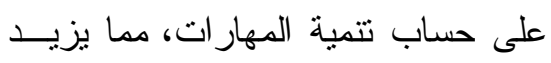

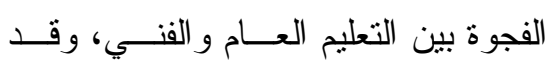

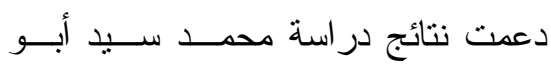

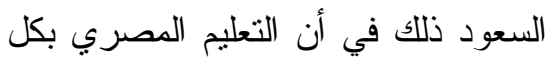

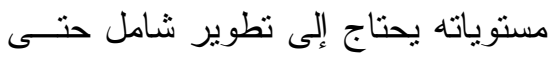




\begin{tabular}{|c|c|}
\hline \multirow{2}{*}{ 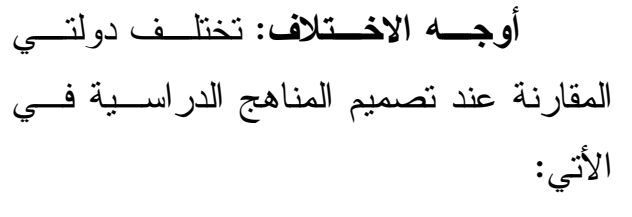 } & المختلفة بالمدرسة، و هـــذا مـــا دعتـــه \\
\hline & 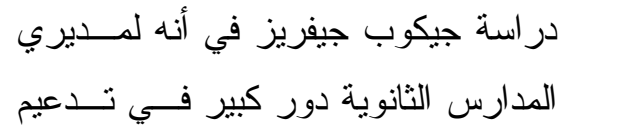 \\
\hline ا ـ في الو لايات المتــــدة تــصمم المنـــــج & التطور ات و التعديلات التكنولوجية التــي \\
\hline بحيث تتيح الوقت للمعلم ليناقش طلابـــه، & تم إذخالها على التعليم الأمريكي(Vץ). \\
\hline ويتعاون الطلاب فيما بينهم لتحسين نتائج & r. في مصر يتم تعيين مديري المدارس تبعاً \\
\hline التعلم، و يدرس كل طالب طبقاً لمهار اته & لعدد سنوات الخبرة دون الكفاءة، ويرجع \\
\hline وقدر اته، ويتفق هذا مع نتــائج دراســة & ذللك إلى ضرورة صعود المعلـــم لــسلم \\
\hline فريدسون سوارز حيث توصل إلــى أن & وظيفي محدد قبل وصوله للإدارة. \\
\hline التو اصل و العلاقة الجيدة مـــع الطـــلاب & ـ ـ في الو لايات المتحدة يتم تعيين المــديرين \\
\hline وتوفير بيئة من الثقة و الدعم النفسي فـي & ممن شهد لهـــ بالابتكــار فــي العـــل \\
\hline مرحلة المر اهقة يـسـاعد علـى زيــادز & و التجديد و القدرة على حـلـ المـشكلات \\
\hline دافعيتهم و إيجابيتهم نحو التعلم (Vr). & الطارئة بكفاءة. \\
\hline r. في مصر بالرغم من الجهــود المبذولــة & ثالثاً:المناهج الدراسية: \\
\hline للتطوير ماز الت المناهج الدراسية تهـنت & أوجه التشابه:تتشابه مصر و الو لايات \\
\hline بالحفظ و التلقين، مما يساعد على شــيو & المتحدة في مجال تصميم المناهج الدراســية \\
\hline الاروس الخصوصية. & ويتضح ذلك مما يلي: \\
\hline r. في مصر تؤكد المناهج الدر اسية علـ & ا ـ ترصد مصر و الولايات المتحدة التمويل \\
\hline التزفع عن العمل اليدوي المنتج. & المناسب لتطــــير المنـــاهج الدراســية \\
\hline عـ توضع المناهج الدر اسية بحيــث ثقابــل & وتعــديلها طبقــاً للمـــتجدات العالميــة \\
\hline التعدد الثقافي في المجتمع الأمريكي، مما & المعاصرة. \\
\hline يعزز تلبية احتياجات كل طالــب طبق & r. تهنم الدولتان بتصميم المناهج الدراسـية \\
\hline 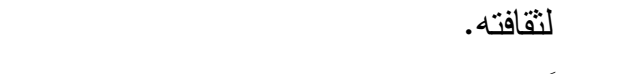 & بطريقة إلكترونية مــن خــلال شـبكات \\
\hline رابعاً: نظم المعلومات والاتصالات: & 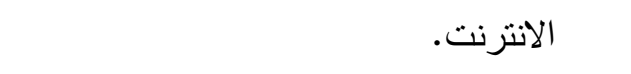 \\
\hline أوجه التشابه:تتشابه مصر و الو لايات & r. تضع دولتي المقارنة المقررات الدراسية \\
\hline المتحدة في مجال تطبيق نظــــ المعلومــان & بحيث نقابل احتياجات الطلاب في هـــه \\
\hline و الاتصالات ويتضح ذلك مما يلي: & 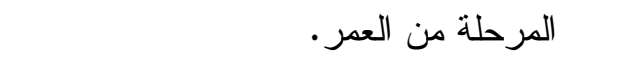 \\
\hline
\end{tabular}


مباشرة من خــلال شــبكة الانترنــــ،

و الفصول الافتز اضبة وربــــ المدرســة

بشبكات تعلم عالمية مـــع مختلـــ دول

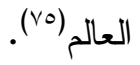

ـ. تهتم الو لايات المتحدة بتطبيــق عمليــة النمذجة و المحاكاة عن طريق الكمبيــونز في عملية الــتعلم ممـــا يجعــل المـــادة التعليمية أن نكون و اقعية أكثز . خامساً:التعلم الابتكارى:

أوجه التشابه:تتشابه مصر و الو لايات المتحدة في مجال تطبيق الــتعلم الابتكــارى ويتضح ذلك مما يلي:

ا ـ تقتع الدولتان بأن التعلم الابتكارى يتـبح اكتشاف القدرات الكامنة لدى الطــلاب، ويساعد على تحسين عملية التفكير لديهم. r. تشجع الأهداف التعليمية للمرحلة الثانوية

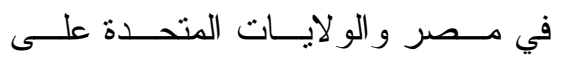
الابتكار ور عاية المبتكرين.

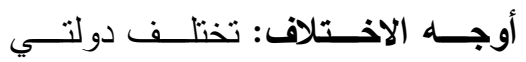

المقارنة في مجال تطبيق الــتعلم الابتــــارى ويتضح ذلك على النحو التالي:

ا. في مصر يتــضح أن الاهنمــام بــالتعلم

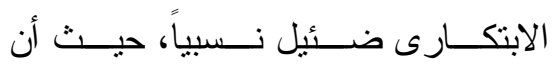
الاقتصاد مبني على الإنتــاجـاجـ التقليــدي، و الذي تؤدي المعرفة فيه دورًا أقل، وقد الأل توصلت در استة ميلوس بارزنين إلـى أن
ا ـ اهتمت الدولتان بتوفير نظم المعلومــات

والاتصالات على نحو جيـــــ بالمدرســـة

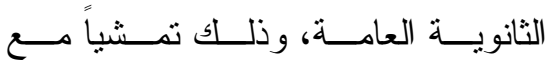

المتطلبات التعليمية في العصر الحديث.

ץ. تؤمن مـــر و الو لايــات المتــــدة أن

تكنولوجيا المعلومات و الاتصـالات مقــوم أساسي لنجاح العملية التعليمية.

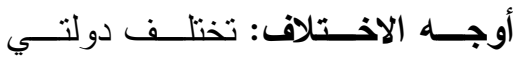

المقارنة في مجال تطبيق نظـــم المعلومـــات

و الاتصالات ويتضح ذلك على النحو التالي:

ا . بالر غم من اهنمام مصر بتفعيـلـ نظــــ

المعلومات و الاتصالات بالمرحلة الثانوية

العامة، إلا أن هذه النظم لـ يتم تفعيلهـا

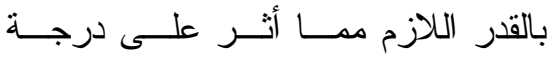

الاستفادة منها، و هذا يتفق مع ما توصلت

$$
\text { إليه در اسة أحمد سعيد( (V). }
$$

r. في مصر لايتم الاستعانة بشبكة الانترنت

في الاتصالات الداخلية والخارجية بـين

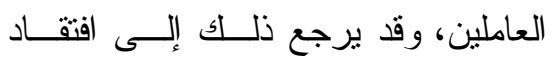

العاملين لمهار ات التواصل الحديثــة، أو

نتيجة نقص تفعيل هذه الثبكات وتتفيذها

بشكل كامل.

r. في الولايات المتحدة تم تفعيل التعلم مــن

خلال الانترنت بشكل أساســي يوميــاً،

و هذا يتفق مع نتــائج در اســـة جيكـــوب

جيفريز حيث توصــلـ إلــى أن و لايـــة

كاليفورنيا قامت بتوفير المــادة العلميــة 


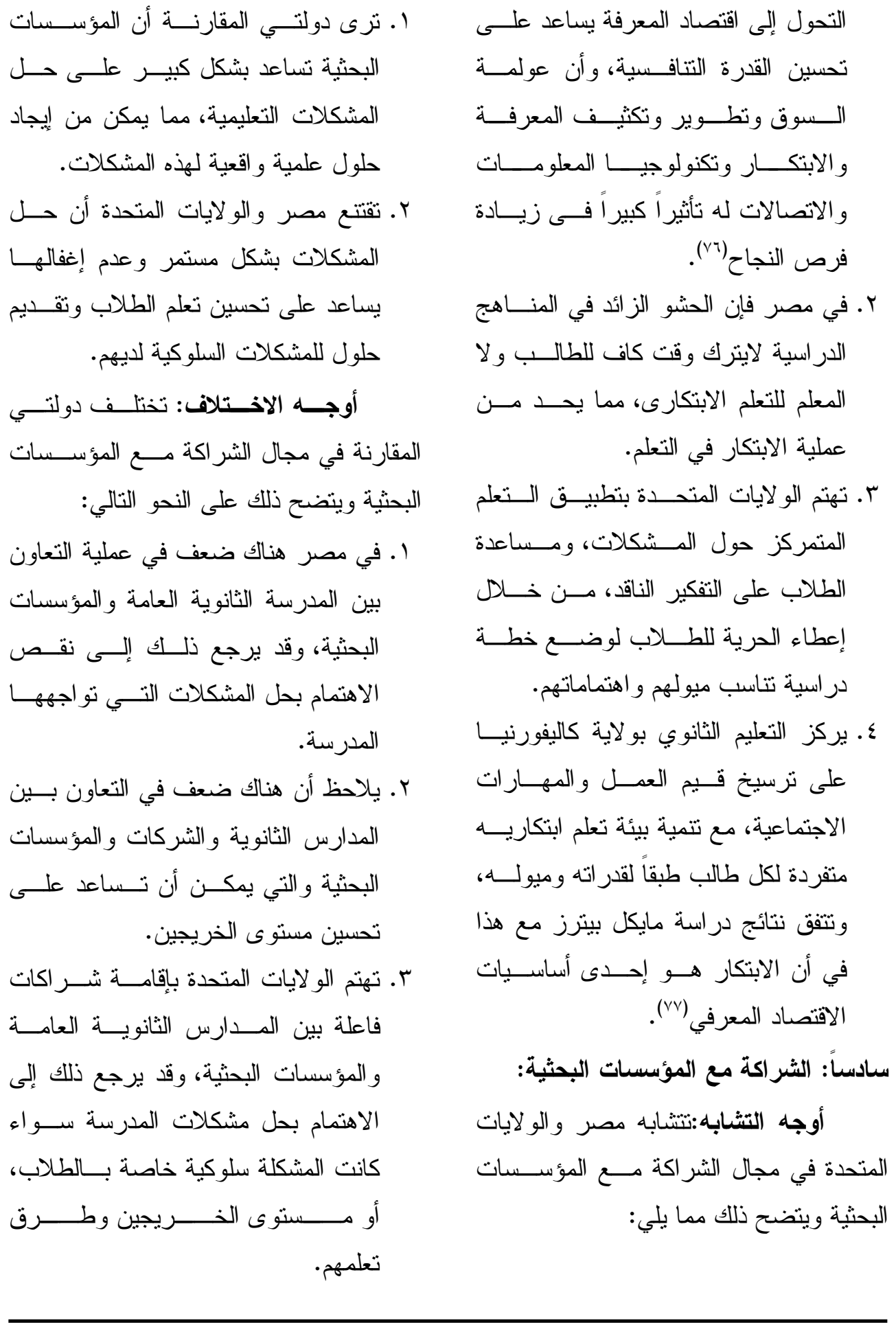


"م. يلاحظ وجود ضعف في التعــاون بــين المدرسة الثانويـــة العامـــة و الــشركات

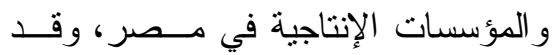
يرجع ذللك إلى غلبة الطابع النظري لهذه المرحلة، وضعف ارتباطها باحتياجــات سوق العمل الإنتاجية و الصناعية، وقـــ توصلت در اسة أحمد عبد الباري إلى أنه من أهم الإصلاحات التي يجب إدخالهــا على المدرسة الثانوية العامة المو اعمة مع

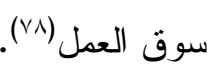
ع. تهتم الولايات المتحــدة بالكـشف عـن الطموحات المهنية للطلاب، مما يـسـاعد على تتمية قدر ات الطالب فــي المجــال الذي يربد العمل فيه في المستقبل. ثامناً:العلاقة مع المجتمع:

أوجه التشابه:تتشابه مصر و الو لايات المتحدة في مجال العلاقة مع المجتمع ويتضح ذلك مما يلي:

ا ـ تقوم المدارس الثانوية العامــة بـــصر و الو لايات المتحدة بإقامة علاقات بصور

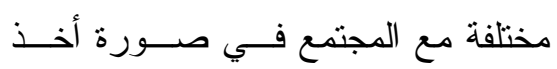
و عطاء. r. تقتتع الدولتان أن العلاقـــة القويــــة مـــع

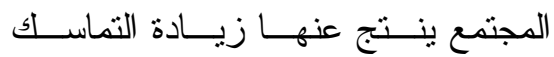

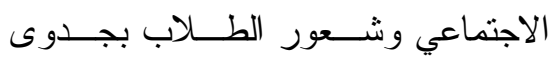
المدرسة.
سابعاً:الارتباط بسوق العمل: أوجه التشابه:تتشابه مصر و الو لايات

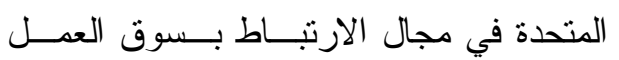
ويتضح ذلك مما يلي: ا ـ تعمل دولتي المقارنة على ربط المدرسة بسوق العمل كضرورة أساسية لتحسـين مستوى الخريج وتطبيق ما درسه بشكل عملي. r. أقامت مصر و الولايات المتحدة وحـــدات داخل المدارس تعمل على توجيه الطلاب لإنتاج منتجات تفيد المجتمع وفى نفس الوقت تسـاعد على تطبيق مـــا درســوه وتخرج قــدر اتهم ومهـــار اتهم الخلاقـــة

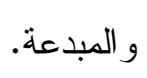

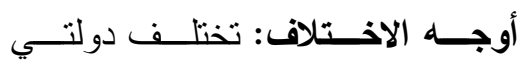

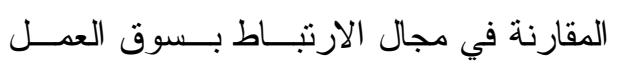
ويتضح ذلك على النحو التالي: ا ـ في مصر يوجد ضــعف فـي التــرويج

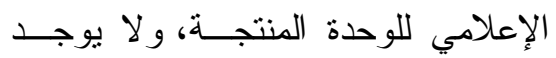
اهتمام بما تتتجه للنفع العام. r. في الولايات المتحدة يتم تدريب الطلاب بشكل فعال ومكثف على خبرات العمل، حيث تقدم الولاية بر امج للتتمية المهنيــة

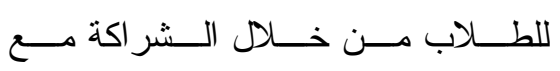
المؤسسات الإنتاجية مما يحسن مـسستوى الخريج. 
و المعلم وولى الأمر في تحديد ما يــروه مناسباً لتعلم الطالب.

هـ كذللك تعمل ولاية كاليفورنيا على إقامسـة

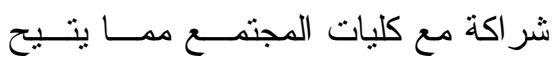
تحسين تعلم الطلاب و إعدادهم للجامعسـة

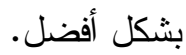

خطة مقترحة لزيادة فعالية المدرسة الثانوية

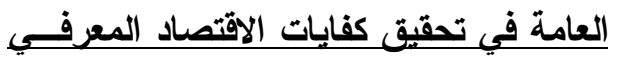
بمصر في ضوء خيرة الولابــات المتحــدة الأمريكية:

بعد استعر اض خبرة مصر و الو لايات

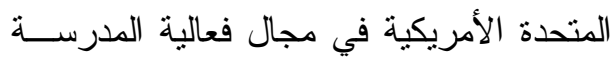
الثانوية العامة في تحقيق كفايــات الاقتــــاد الاديه المعرفي، يمكن وضع تصور خطة مقترحسـة

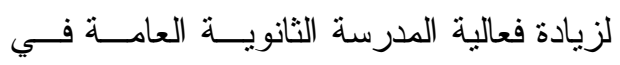

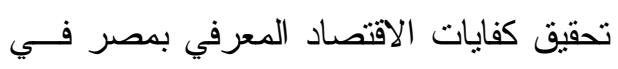
ضوء خبرة الو لايات المتحدة الأمريكية وذلك على النحو التالي: أولاً. السياسات التعليمية بالتعليم الثـانوي العام: - الام:

ا ـ تبنى الدولة ككل في جميــع قطاعاتهـــا

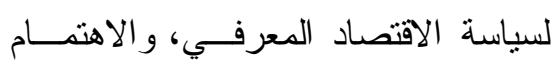

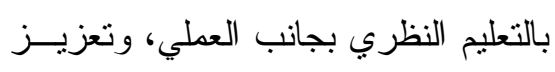
فكرة العمل المنتج. r. تقليل الفجوة بين التعليم العـام و الفنـي،

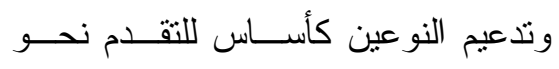
الاقتصاد المعرفي.

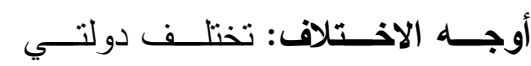

المقارنة في مجــال العلاقــة مــع المجتمـــع ويتضح ذلك على النحو التالي:

ا ـ في مصر يوجد ضعف في العلاقة بـين

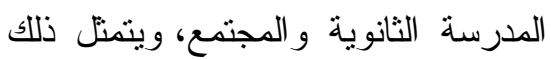
في نقص إقبال الأسرة على التعاون مـــع ولئحن المدرسة، وكذلك ضعف حفز المدرســة للأسرة على التعاون معها، وقد توصلت دراسة أحمد عبد الباري إلى أنه من أهم

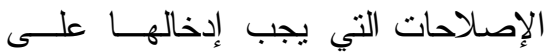

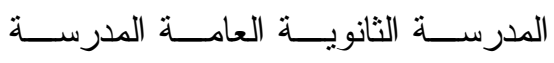

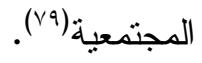
r. في مصر لا يوجد عقد اجتماعي محسـدد يوضح دور الأسرة فــي التعـاون مـــع

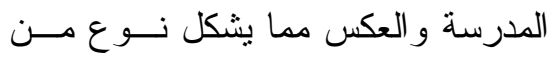
العزلة بين الاثثين. r. في الولايات المتحدة يقوم الطلاب بخدمة

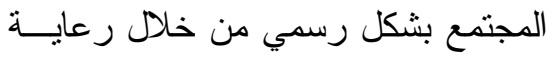

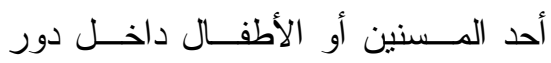
الرعاية وغير ها، مما يساعد على تثكيل

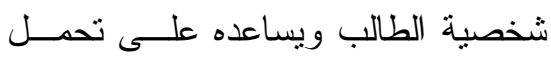
المسئولية فيما بعد. ع. يشارك الطلاب و المعلمين أولياء الأمور

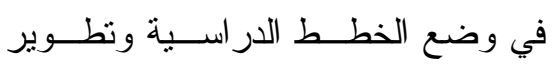

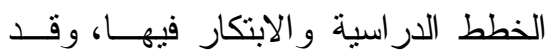
يرجع ذللك إلى الطابع اللامركزى للتعليم

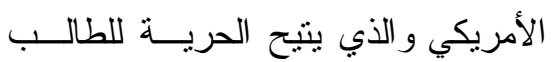


ثالثاً: المناهج الدراسية:

ا ـ استخدام مناهج وأساليب تدريسية تركــز على التعلم الفعال. r. إعطاء الطلاب وقـت كــاف للتحــدث و القر اءة و الكتابة و التفكير داخل الفصول سو اء بمفردهم أو في جماعات صغيرة. r. ربط المدارس الثانوية العامة بشبكة عمل

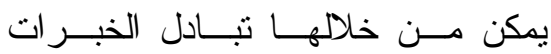

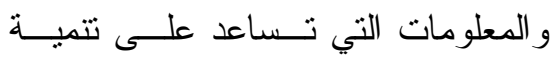

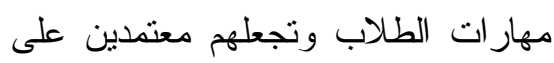
أنفسهم في عملية التعليم و التدريب.

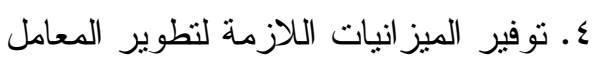
وأجهــزة الحاســـب الألــــى، و المكتبـــــة

$$
\text { المدرسية. }
$$

ه. الحد من الدروس الخصوصية وذلك بسن القو انين التي تعاقب من يقوم بذلك.

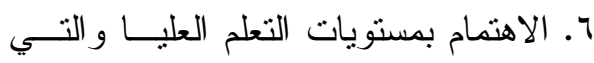
تتضمن التحليل و التركيب و التقويم بجانب

$$
\text { الحفظ و الفهم و التطبيق. }
$$

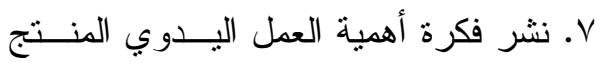
ودورة في تحقيق الاقتصاد المعرفي. رابعاً:نظم المعلومات والاتصالات:: ا. زيادة فعالية وحسـدة نظـــم المعلومــات

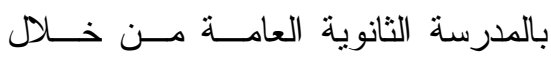
تــسجيل المعلومــــات الإســـــز اتيجية، و المالية، ونتائج الطلاب وكل ما يخــص لــل

$$
\text { المدرسة. }
$$

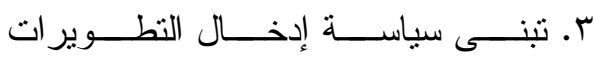

و التحسينات بالمدرسة الثانويــة العامــة

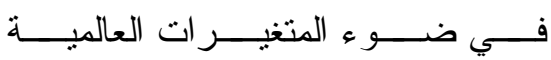

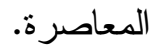

عـ التكامــلـل بــين الـــياسات التعليميـــة

الموضوعة و الأهداف المرحلية المطبقـــة

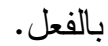

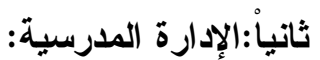

ا ـ زيادة وعى مديري المدارس بالأسـاليب

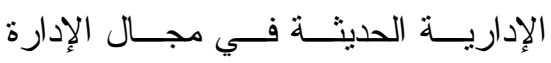
المدرسية، مع تدعيم الابتكار لديهم.

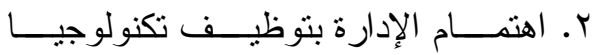

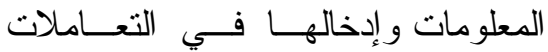
اليومية داخل المدرسة. r. تتمية مهار ات وقدرات العاملين الإدارية، بما يوازي التجديدات و التغيير ات الحادثة داخل المدرسة الثانوية. ـ. اختيار مدير المدرسة على أساس الكفاءة

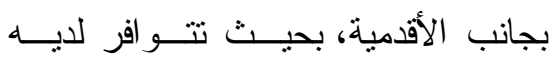

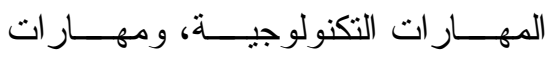
التو اصل والابتكار حتى يتماثـى مـــع منطلبات الاقتصاد المعرفي. ه. تطبيق الإدارة الإلكترونيــة بالمدرســة

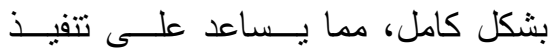

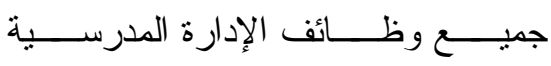
إلكترونياً. 
r. التركيز على الكيفية التي يستطيع بها كل

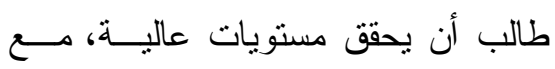
تتمية بيئة تعلم متفردة، و الاهتمام بأنشطة يو مية مبتكرة. ع. تصميم الخطط الدراسية بحيث تتتاسـب مع اهتمامات الطلاب ومو اهبهم الخاصة و هو ما يغرس فــيهم مهــار ات العمـلـل و المهار ات الاجتماعية.

سادساً:الثر اكة مع المؤسسات البحثية: ا ـ إقامة شر اكة ناجحة بين المدرسة الثانوية العامة و المؤســسات البحثيــة و التقنيــة

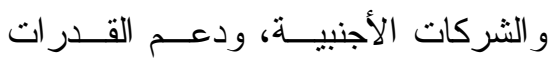
الداخلية للاستفادة من انتـشار المعرفـــة و الانفتاح على العالم الخارجي. r ـ تشجيع تبادل المعلومــات بــين مــصر

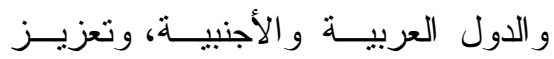
الكفاءات العلمية وصناعة المعرفة و التي

$$
\text { هي لب الاقتصاد المعرفي. }
$$

ب. الاستشارة المستمرة للجهـات البحثيــة

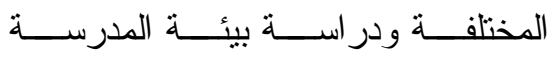

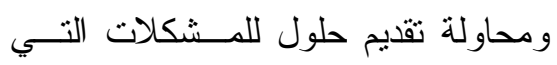

$$
\text { تو اجهرا. }
$$

ـ ـ تتميــــة الكفايـــات المهنيــــة للمعلمــين

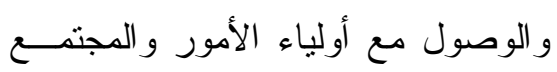
لأفضل تدعيم للمدرسة. r توفير شبكة معلوماتية للعاملين تفيد فـي

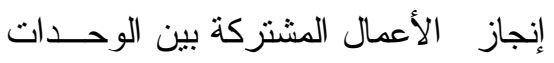

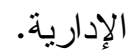
r. استخدام شبكة الإنترنت في اتـصالاتها

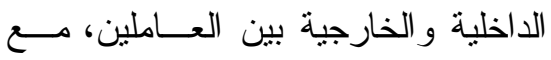
توفير أجهزة الحاسب الألى بشكل كافي. ع. مساعدة الطلاب على اختبــار المعلومـات

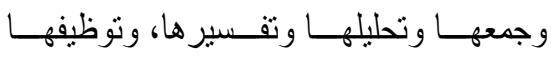

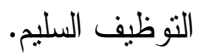

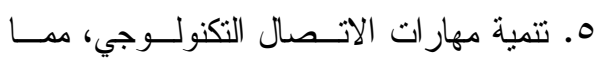

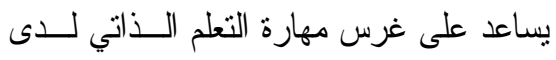
الطلاب و التعليم المستمر طو ال الحياة. 7. توظيف تكنولوجيا التعليم في نقل المعرفة وتوصيلها للطلاب، وبناء نموذج مرجعي

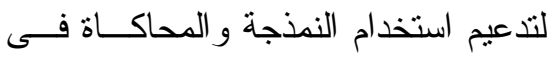
عملية التعلم.

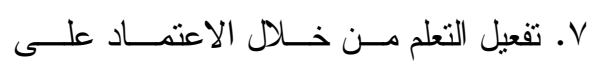
الإنترنت و البريد الإككتروني و المــصـادر المتعددة للمعلو مات. خامساً:التعلم الابتكارى :

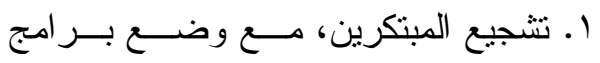
تدريبية لتتمية قدر ات المبدعين منهم. r. تطوير الكتاب المدرسي بحيـــث يركــز على التعلم المتمركز حول المـشكلات، وحث المعلمين للطلاب على تتمية الفكر الإبداعي الناقد. 
7. إتاحة فرص مهنيــة للطــلاب لخدمــة المجتمع، من خلال القيام بخدمة مجتمعية

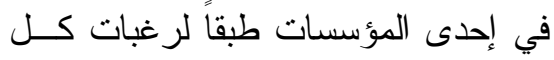
طالب.

r. تدعيم مشاركة أولياء الأمور و أعـضـاء هيئة التدريس بالجامعات ورجال الأعمال

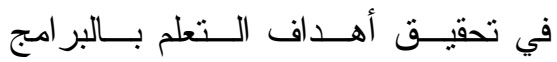
الأكاديمية التي تقدم للطلاب. r. تحديد الحقوق و الو اجبات بــين الأســرة

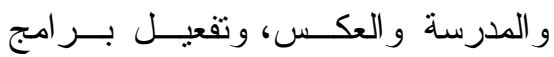

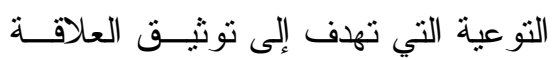
بينهما وتطوير ها.

ع. تخصيص قاعة للفيديو كونفرنس تيـسر

الاتصـال مع المجتمع، وتساعد المدرســة فئة على إيجاد مناخ من الثقة بينهـــا وبـين التين الأسرة من خلال الاجتماعات و اللقاءات والأشطة المختلفة.

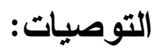

بعد استعر اض البحث فعالية المدرسة

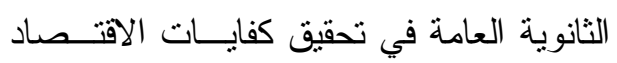

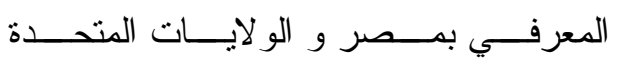

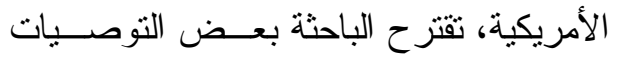

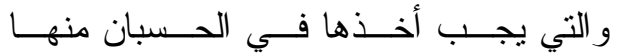
ما يلي:

ا ـ ابتكار نظام فعال من الروابط التجاريـــة بين الشركات ومنظمات الأعمال وبـين المؤسسات العلمية و الأكاديمية.
سابعاً:الارتباط بسوق العمل:

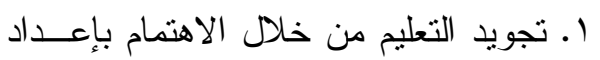
الأيدي العاملة المتخصصة كثيفة المعرفة عالية المهارة في التعامل مع المعرفة. r. زيادة وضوح الأهداف التزبوية للوحــدة

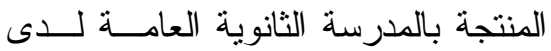
مديري المدارس و المعلمين و الطلاب. r. إقامة شر اكة مع المؤســـات الإنتاجيــة

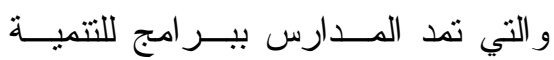

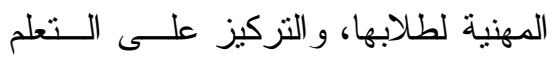

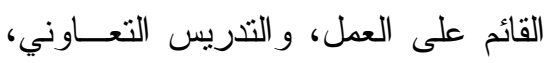

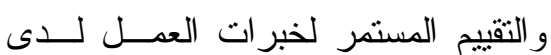
الطلاب

ـ. وعي المعلمـين بالطموحــات المهنيــة للطلاب يساعد على تحسـسين الفـرص بـرص المتاحة لخريجـي المدرســة الثانويــة، ويساعدهم على تحقيق مهـــار ات مهنيــــة عالية. ه. تدعيم الابتكار داخل الوحدة، مع الترويج

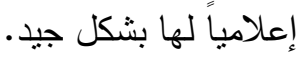

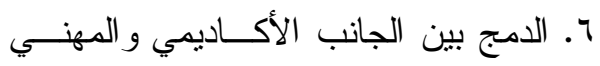
للطلاب، مع ربط التعليم بعالم العمل من

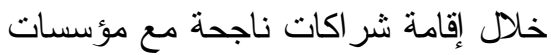
الأعمال. خالأ. ثامناً:العلاقة بين المدرسة والمجتمع: ا ـ تفعيل قنوات الاتصال بين الطلاب و الآباء و المجتمع، وجذب أولياء الأمور وتفعيل دور هم في تعليم أبنائهم. 
9 ـ زيادة وعى العاملين بالمدرسة بمغــى

عمليات الإصلاح المدرسـي، وحتميتــهـ

لمو اكبة التغير ات المعرفية و التطــــور ات اتل التكنولوجية السائدة في المجتمع.

• ا. اعتماد البنية التحنية على تكنولوجيـا

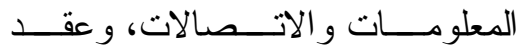

الاجتماعات لتلقـى أســئلة العـاملين

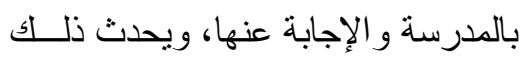

من خلال التدريب المستمر بالمديريات

التعليميــة وعبــر شــبكة الفيـديو

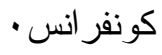

الـ ألا يقف التعليم الثانوي عند حد تعلــيم

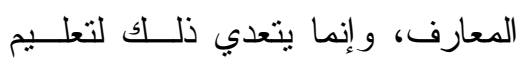

المهار ات اللازمة للنجاح في الحيــاة،

حيث أنه المــدخل الحقيةـي لعـــر

$$
\text { الإنتاج كثيف المعرفة. }
$$

r ا . زيادة استخدام التقنية التعليمية، و إحلا

الحاسب الآلى وجميع نطبيقاته التقنبــة ولنة

محل العمل اليدوي الروتنيني، بحيــــ يشتمل جميع العمليات الإدارية و المالية و الإجر ائية و التعليمية الممكنة.

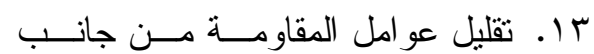
العاملين للإصلاح المدرسي، وذلك عن طريق الاتصال وشرح أسباب التغيير

$$
\text { وتحديد أبعاده . }
$$

r . جعل تكنولوجيا المعلومات و الاتـصالات أكثر إتاحة ويسر ، مع تخفيض التعريفات الجمركية المفروضة علــى المنتجــات التكنولوجية، وزيادة القــدرة التتافـسية للمؤسسات الصغيرة و المنوسطة. r. تطوير المناهج بجميع مر احسل التعلــيم

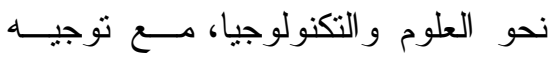

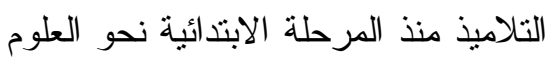
و التكنولوجيا. ــ العناية بمر اكز مصـادر وتقنيات التعلــيم،

$$
\text { واستحداث المدارس الذكية وتعميمها. }
$$

هـ العناية بالقيادات التربوية و واعتماد مبـــــأ اللامركزية في الشؤون التتفيذية.

7. إدخال الحاسب الآلي والارتباط بـشبكة

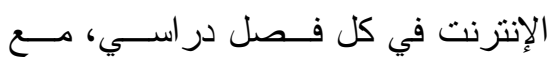
الربط بين التعليم و أنشطة البحوث.

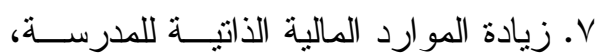
وتمكين المدرسة في الأمــور الماليــة، و اســـتغلال التكنولوجيـــا، و المــشاركة المجتمعية. ^. دعم عمليات التغيير داخـلـ المدرســة علـى المستوى الفردي و التنظيمي وتوفير مقومسات

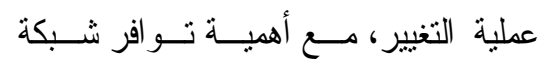
معلوماتية للعاملين تفيدهم في إنجاز الأعمـال المشتركة بين الوحدات الإدارية. 
V- بشير صالح الرشـــيدي،منــاهج البحــث

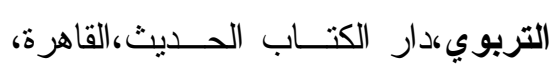

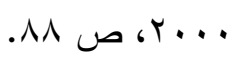

1- زكريـــــــــالم ســليمان،"تطـــــير الأداء

الإداري بالمدارس الثانوية العامة بمصر لطرئر

في ضوء مدخل إدارة المعرفة ــ تصور

مقترح"، رسالة ماجستير ، كلية البنات ، جامعة عين شمس ، ر . . r.

9- محمد سيد أبو السعود، تطـــوير التعلــيم

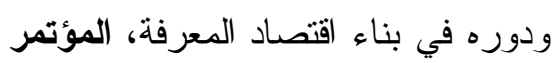

الاولي الأول للتعلم الاكتروني واهني لتعليم

عن بعد، وزارة التعليم العالي بالتعاون

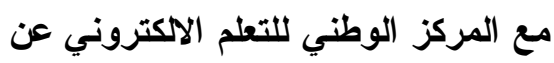

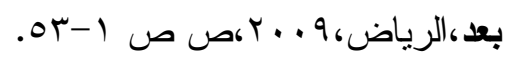

• 1-سعد خضير عباس، الاقتصاد المعرفـي

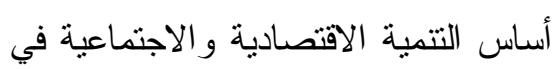

الدول العربية، مجو ا،عء؛، مجلة كليـة

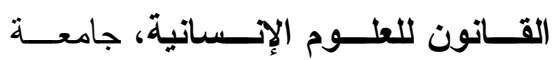

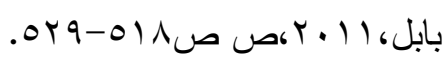

11-أحمد حامـــد النقـادى، دور الاقتــــاد

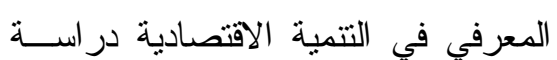

تحليلية بالتطبيق على الاقتصاد السعودي،

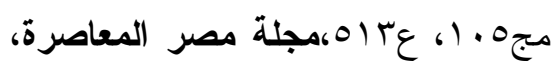

الجمعية المصرية للاقته صـاد الـسياسي مصني المعاهره

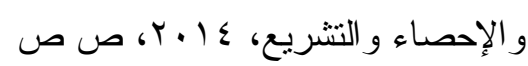

.rVY-YOI
قائمة المراجع: - إن

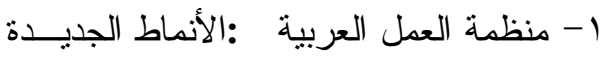

للتشغيل، مؤتمر العمل العربي، الــدورة

الر ابعة والثلاثون، شرم الثيخ، جمهورية

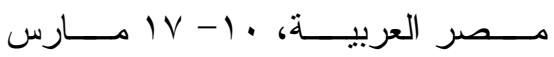

.

r- عبد الله محمد فرج: التعلــيم الثـانوي

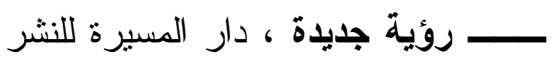

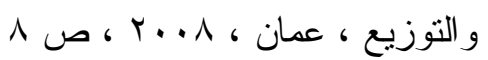

3- Xiao, P., Communication and Innovation in Cooperatives, Journal of knowledge economy, V. 9, n. 4, December 2018,p.p. 1184-1209.

4- Sirine ,M., Effects of Technological Shock on Employment: Application of Structural Approach VECM, Journal of knowledge economy,, $\mathrm{V}$. 9, n. 4, December 2018,p.p. 1138-1153.

5- Marwa,s., Education and Corruption: a Stochastic Frontier Analysis: Evidence from Developed and Developing Countries, Journal of knowledge economy, February 2019, P.p1-14.

7- منظمة العمل العربية :الأنمـاط الجديــدة

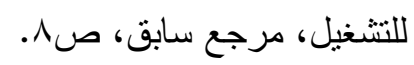


17-Fredson,S., The Relation between Teacher and Students in the Classroom: Communicative Language Teaching Approach and Cooperative Learning Strategy to Improve Learning, ITEM 22,BSU Maser's Theses and Projects, college of graduate studies, Bridgewater State University,2015.

18-Jacob,p.; The Role of Cyber School Principal: Amixed Methods Study, Phd Dissertations, college of graduate studies, University of Nebraska, 2015.

19- Catherine,D.,Teacher+Technol ogy=Blended Learning:How Important is the Teacher in this Equation?, ,ITEM 271, Educational Administration Thesis, Dissertation and Student Reserch, University of Nebraska,2016.

20-Eustache.,M., Correlation Between Transmission Power and Some Indicators Used to Measure the Knowledge-Based Economy: Case of Six OECD Countries, Journal of knowledge economy,v. 9, n. 4, December 2018,pp 1168-1183.

21-The World Bank. World Development Report 2019: The changing nature of work, Washington, DC, World Bank, 2019, 151 pp.

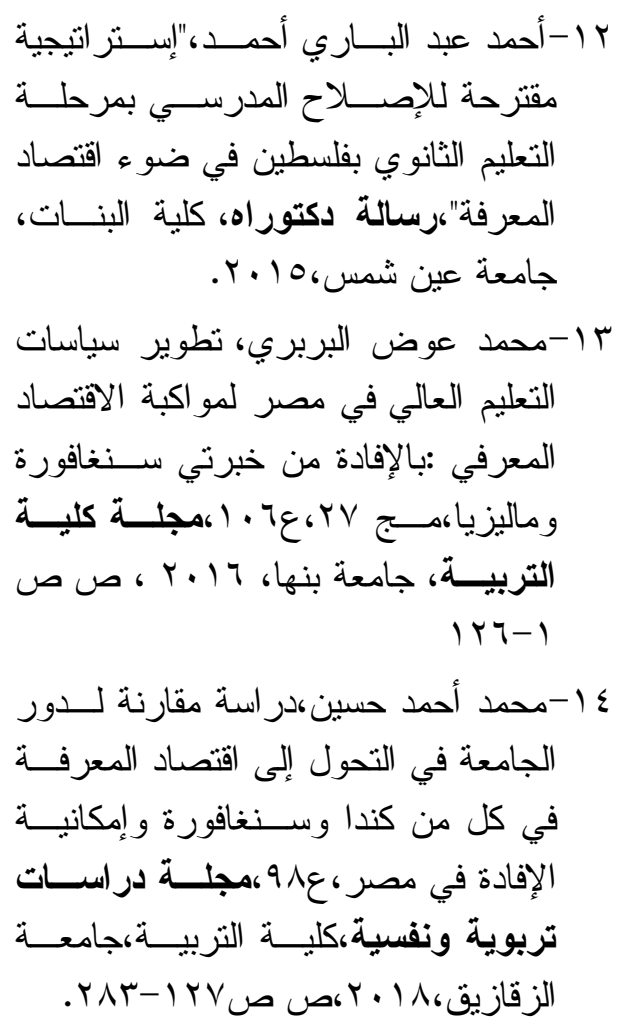

15-Michael A., Three Models of Imagination in the Age of the Knowledge Economy, Journal of higher education, $V$. 63, n. 3, march 2012,pp 373395.

16-Milos,p., The Influence of the Knowledge-Based Economy on the Competitiveness of European Economies and Businesses, journal of Innovative Management and Firm Performance ,2014, pp 68-90. 
The Journal of Technology

Studies, v. xxx, n.3, Summer 2004, p. 54.

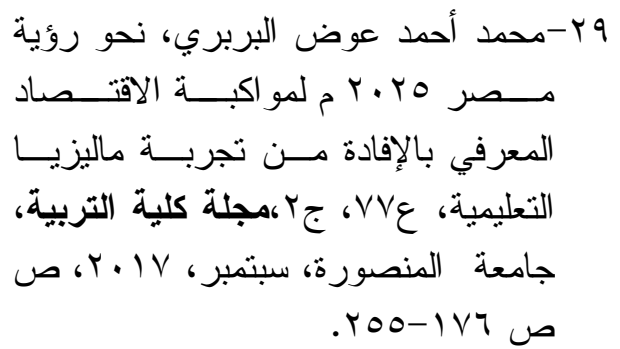

30- Marjorie ,1.,

SME

Internationalization: the Impact of Information Technology and Innovation, Journal of knowledge economy, January 2019,p.p.1-20.

اس-محمد إبر اهيم عطوة مجاهد، ديمقر اطية التعليم وتكافؤ الفرص التعليميــــة داخــلــل

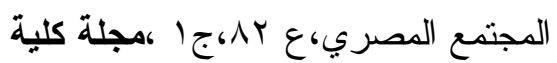

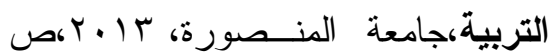
ص ص الر

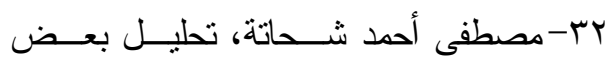

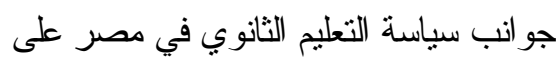

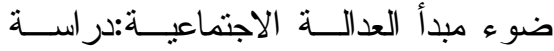

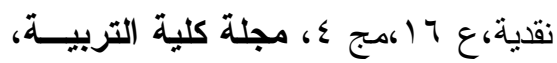

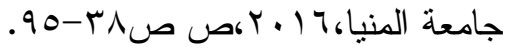

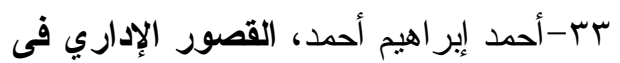

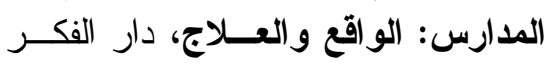

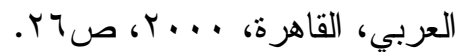

؟r-سامح حلمي حواش، "دور الحاسب الآلي في حل بعض مشكلات الإدارة المدرسية لدرية في المدارس الثانوية العامة في جمهورية الإدانة

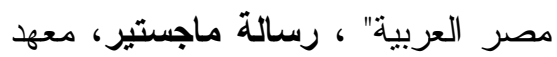

22-Marzano, R. \& et al: School Leadership That Work; From Research to Results, ASCD, Alexandria, USA, 2005, P.18.

بr-مصطفى محمد منديل، "تقــويم كفايــات

معلمي ذوى صعوبات التعلم في ضــــوء

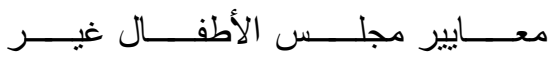

العاديين(cec) من وجهة نظر المشرفين

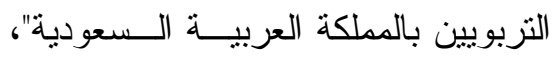

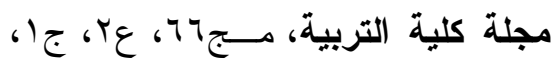

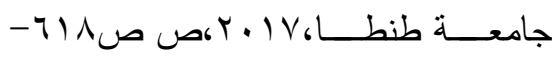
.707

24-Advancing Knowledge and the Knowledge Economy, OECD, Research DirectorateGeneral , European Commission, 11- 15 January 2005.

هץ-فليح حسن خلف : ا(تتصاد المعرفة، عالم

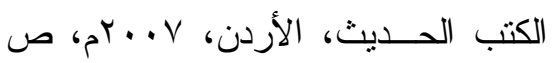
$. r \leq$

26-On the internet at: http://www.Actim,org. eg/ admin/ Farek pal/ ARABSTRATEGY- ARAFT accessed date: 10-1-2019

27-Myong-Hun An,G., Intellectual Product and Method of Assessing the Competitiveness of an Enterprise with It, Journal of knowledge economy, February 2019, pp $1-27$

28-Mustapha, R., Malaysia Transitions Toward a Knowledge- Based Economy, 
40-Hella,b., Does Patent

Performance Promote Relative

Technological Performance in

Countries Bordering the

Mediterranean?, Journal of

knowledge

economy,

, V.9, n.4, December 2018, pp 1246-1269

41-Roper, A.; ICT in Education in

Egypt, Survey for ICT and

Education in Africa- Egypt

Country, June 2007.(http: //

www. Infodev. Org/ en/

Publication. 399. Html).

accessed date: 2-2-2019

rع -أحمد حامــــ النقــادى، دور الاقتــــاد

المعرفي في التتمية الاقتصادية دراســة

تحليلية بالتطبيق على الاقتصاد السعودي،

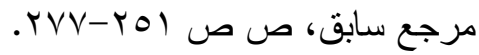

43- Sergey,m.,

Knowledge

Exchange and the Trust

Institution: a New Look at the

Problem, Journal of

knowledge economy, February 2019, pp 1-17.

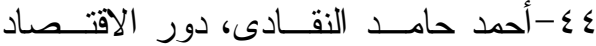

المعرفي في التتمية الاقتصادية دراســة

تحليلية بالتطبيق على الاقتصاد السعودي،

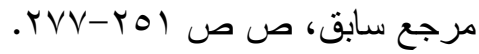

الدر اسات و البحوث التربويـــة ، جامعـــة

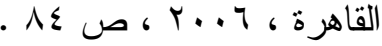

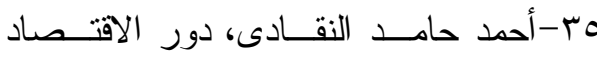

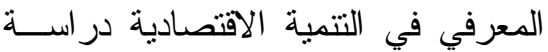

تحليلية بالنطبيق على الاقتصاد السعودي،

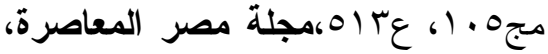

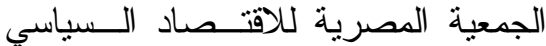

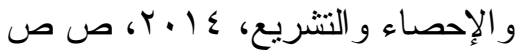
. TVV-YOI

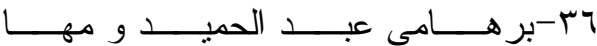

عادل،استخدام الألعاب التعليمية الرقميــة في تتمية مهار ات حل المشكلات في مادة الرياضيات المالية لدى طلاب المـــدارس فئ فئس الثانوية الفنبة المتقدمة التجارية،مج 74

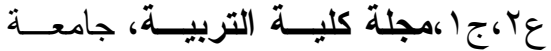

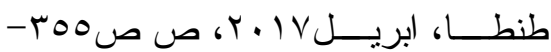
. rVI

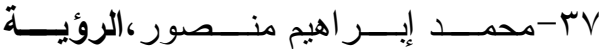

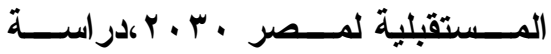

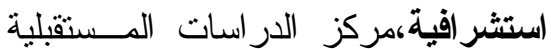

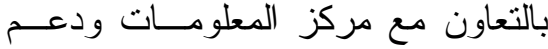

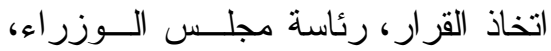

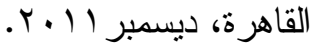

رب- أحمد محمد سعيد إير اهيم، فعالية جودة المنظومة

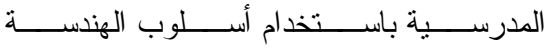
الإدارية،رسالة دكتوراه، كلية التربية،جامعة قناة

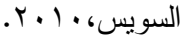

39- The Economist; Waking from its sleep- A special report on the Arab world, 25/6/2008, p. 14. 
Nongovernmental

Organizations, Comparative

Education Review, v. 54, n. 4, November 2010, p. 577.

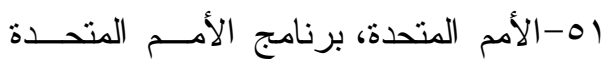

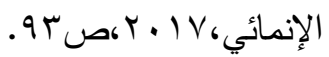

52-on the internet at:

http://www.voltairenet.org accessed date:2-2-2019.

53-on the internet at :http://www.sacm.org accessed date:4-2-2019

54-on the internet at :http://www.politicalencycloped ia.org accessed date:5-2-2019

55-Akhavan, P.; Exploring the Interdependency between Reengineering and Information Technology by Developing a Conceptual Model, Business Process Management Journal, V.12, n.4, 2007.

56-Bhatt, G.: Exploring the Relationship between Information Technology Infrastructure and Business Processes Reengineering, Business Process Management Journal, v. 6, n. 2، 2007, p.144.

57-Tomlinson, H.; Educational Leadership - Personal Growth for Professional Development, SAGE publications, London, 2004, P. 106.

58-on the internet at: http://www.highschoolrenewal.
45-OECD(Organisation for

Economic Co-operation and

Development), The Challenge

Of Promoting Youth

Employment in G20

Countries,OECD Publishing,

OECD Centre for

Educational Research and

Innovation, Paris, 2012.

7؟-السيد أحمد عبد الغفــار، دور التعلــيم

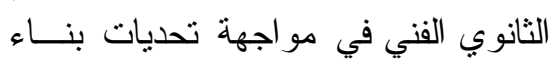

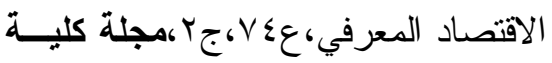

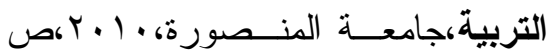

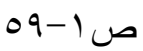

47-ILO.Global Employment Trends 2013:Recovering From a Second Job Dip., International Labour Office ,Geneva, 2013.

^ـ -عبد اللطيف حسين فرج، نظم التربيــة

و التعليم في الوظن العربي ما قبل وبعد

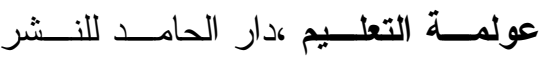

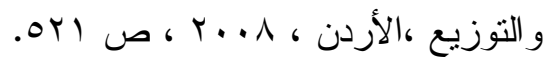

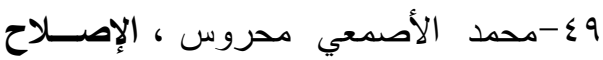

التربوي والثراكة المجتمعية المعاصرة

من المفاهيم إلــى التطبيــق ، ط ب ك،دار

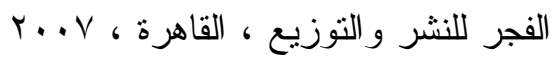

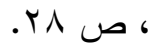

50-Bromley, $\quad$ P.; $\quad$ The Rationalization of Educational Development: Scientific Activity among International 
Schools, (http://www.sdcs.k12.c a.us/hsrenewal/alt_adu.html) accessed date: $19-\overline{2}-2019$

65-Boston High School Renewal : Small Schools Initiative . (http://www.jff.org/approches/y outhtrans/showcase/bostonhsre newal.htm) . accessed date:192-2019

66-High School Renewal: San Diego City Schools, (http://www.sdcs.k12.ca.us/hsre newal/ accessed date:19-2-2019

67-On the internet at: http://www.highschoolrenewal. org/summty.htm accessed date:1-2-2019

68-Community Engagement ,High School Renewal : San Diego City Schools, (http:// www.sdcs.k12.ca.us/hsrenewal/ Community.html) accessed date:1-2-2019

69-on the internet at :http://www.uobabylon.edu accessed date:4-2-2019

• • Vحمد سيد أبو السعود، تطوير التعلــيم

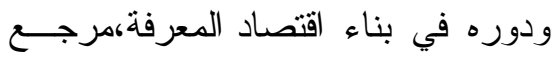
سابق.

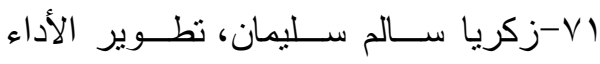

الإداري بالمدارس الثانوية العامة بمصر

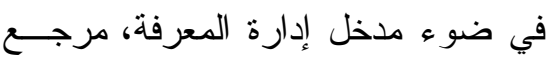
سابق.

72-Jacob ,p.; The Role of Cyber School Principal :Amixed Methods Study, op., cit org/summty.htm. accessed date:15-2-2019

59-Freestanding Schools, High School Renewal ,San Diego City Schools ,(http:// www.sdcs.k12.ca.us/hsrenewal/ Freestanding.html )accessed date:20-2-2019

60-Laframboise, K.; An Examination of the Role of Information Technology as an Enabler to Business Process Reengineering,

PhD

Dissertation, The Faculty of Commerce and Administration, university of Concordia, 2006, P.34.

61-on the internet at: http://www.highschoolrenewa l.org/summty.htm. accessed date:19-2-2019

62-Ann,C.,How Do Firms Perceive Interactions with Researchers in Small Innovation Projects? Advantages and Barriers for Satisfactory Collaborations, Journal of knowledge economy,January 2019,pp1-23

63-Challenge High School Renewal : San Diego City Schools, On the internet at :http:// www.sdcs.k12.ca.us/hsrenewal/ challenge.html. accessed date:22-2-2019

64-Alternative Small Schools, High School Renewal: an Diego City 


$$
\begin{aligned}
& \text { European Economies and } \\
& \text { Businesses, op.cit. } \\
& \text { 77-Michael A., Three Models of } \\
& \text { Imagination in the Age of the } \\
& \text { Knowledge Economy,op., cit. } \\
& \text { - V^ }
\end{aligned}
$$

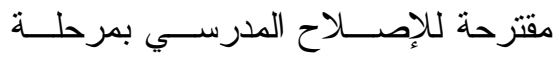

$$
\begin{aligned}
& \text { التعليم الثانوي بفلسطين في ضوء } \\
& \text { المعرفة،مرجع سابق. } \\
& \text { V9 أحمد عبد الباري أحمــد، إســتر اتيجية }
\end{aligned}
$$

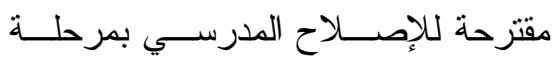

$$
\begin{aligned}
& \text { التعليم الثانوي بفلسطين في ضوء القتصاد }
\end{aligned}
$$

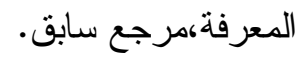
73-Fredson ,S., The Relation between Teacher and Students in the Classroom: Communicative Language Teaching Approach and Cooperative Learning Strategy to Improve Learning, op., cit.

$$
\begin{aligned}
& \text { V - أحمد محمد سعيد إير اهيم، فعالية جودة }
\end{aligned}
$$

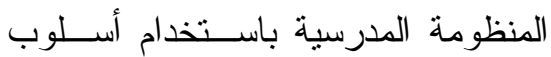

$$
\begin{aligned}
& \text { الهندسة الإدارية،مرجع سابق. }
\end{aligned}
$$

75-Jacob, p.; The Role of Cyber School Principal: Amixed Methods Study, op., cit.

76-Milos, p., The Influence of the Knowledge-Based Economy on the Competitiveness of 